\title{
1 A Statistical Framework to Identify Cell Types Whose Genetically Regulated \\ 2 Proportions are Associated with Complex Diseases
}

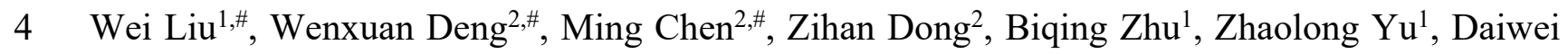
5 Tang ${ }^{2}$, Maor Sauler ${ }^{3}$, Louise V. Wain ${ }^{4,5}$, Michael H. Cho ${ }^{6,7}$, Naftali Kaminski ${ }^{3}$, Hongyu Zhao ${ }^{1,2, *}$

$7 \quad{ }^{1}$ Program of Computational Biology and Bioinformatics, Yale University, New Haven, CT, USA

$8 \quad 06510$

$9 \quad{ }^{2}$ Department of Biostatistics, Yale School of Public Health, New Haven, CT, USA 06510

$10{ }^{3}$ Pulmonary, Critical Care and Sleep Medicine, Yale School of Medicine, New Haven, CT, USA

1106510

$12{ }^{4}$ Department of Health Sciences, University of Leicester, Leicester, United Kingdom

$13{ }^{5}$ National Institute for Health Research, Leicester Respiratory Biomedical Research Centre,

14 Glenfield Hospital, Leicester, United Kingdom

$15{ }^{6}$ Channing Division of Network Medicine, Brigham and Women's Hospital, Harvard Medical

16 School, Boston, MA

$17{ }^{7}$ Pulmonary and Critical Care Medicine, Brigham and Women's Hospital, Harvard Medical School,

18 Boston, MA.

19 \# These authors contributed equally to this work

$20{ }^{*}$ To whom the correspondence should be addressed

21 Dr. Hongyu Zhao,

22 Department of Biostatistics

23 Yale School of Public Health

2460 College Street,

25 New Haven, CT, 06520, USA

26 hongyu.zhao@yale.edu

28 Keywords: GWAS; cell type proportion imputation; single cell data; complex traits 
medRxiv preprint doi: https://doi.org/10.1101/2021.02.25.21252462; this version posted March 1, 2021. The copyright holder for this preprint (which was not certified by peer review) is the author/funder, who has granted medRxiv a license to display the preprint in perpetuity.

It is made available under a CC-BY-NC-ND 4.0 International license.

\section{Abstract}

31 Finding disease-relevant tissues and cell types can facilitate the identification and investigation of

32 functional genes and variants. In particular, cell type proportions can serve as potential disease

33 predictive biomarkers. Here, we introduce a novel statistical framework, cell-type Wide

34 Association Study (cWAS), that integrates genetic data with transcriptomics data to identify cell

35 types whose genetically regulated proportions (GRPs) are disease/trait-associated. On simulated

36 and real GWAS data, cWAS showed substantial statistical power with newly identified significant

37 GRP associations in disease-associated tissues. More specifically, GRPs of endothelial and

38 myofibroblasts in lung tissue were associated with Idiopathic Pulmonary Fibrosis and Chronic

39 Obstructive Pulmonary Disease, respectively. For breast cancer, the GRP of blood CD8 ${ }^{+} \mathrm{T}$ cells

40 was negatively associated with breast cancer (BC) risk as well as survival. Overall, cWAS is a

41 powerful tool to reveal cell types associated with complex diseases mediated by GRPs. 
medRxiv preprint doi: https://doi.org/10.1101/2021.02.25.21252462; this version posted March 1, 2021. The copyright holder for this preprint (which was not certified by peer review) is the author/funder, who has granted medRxiv a license to display the preprint in perpetuity.

It is made available under a CC-BY-NC-ND 4.0 International license .

\section{Introduction}

43 Despite the great success of genome-wide association studies (GWAS), it has been challenging to

44 identify disease-causing genes and variants. To better design functional studies of GWAS

45 implicated SNPs, it is important to identify tissues and cell types most relevant to a disease. Several

46 statistical approaches have been developed for this purpose ${ }^{1-3}$. In general, these methods aim to

47 detect statistically significant overlap between GWAS signals and annotated functional regions in

48 specific tissues and cell types, where the annotated functional regions are curated from other data

49 sources, such as ENCODE and Roadmap Epigenomics data and single cell data. Although such

50 analyses have led to novel insights on disease mechanisms ${ }^{1,4-7}$, the cell types associated with the

51 majority of genomic regions remain to be discovered.

53 Several studies have found that the proportions of cell types are not only associated with disease

54 incidence $^{8,9}$ but also disease prognosis ${ }^{10,11}$. Single cell RNA-seq (scRNA-seq) technologies have

55 been used to identify cell type proportions that impact human diseases and traits ${ }^{12}$. However,

56 several intrinsic characteristics of single cell data make disease-cell type proportion association

57 analysis challenging. First, high expense and technical noise (e.g., high sparsity of gene expression)

58 limit the number of samples analyzed and quality of cell type composition estimation, leading to

59 low power in association analysis. Second, cell type compositions measured in single cell

60 experiments are highly dependent on the biopsy samples and do not necessarily reflect the true cell

61 type compositions in the corresponding tissue ${ }^{13}$. Instead of directly calculating cell type

62 proportions from scRNA-seq data, cell type proportions can also be inferred through

63 deconvolution of bulk RNA-sequencing (RNA-seq) data available with larger sample sizes. Many

64 computational methods have been developed to estimate cell type proportions in bulk RNA-seq 
medRxiv preprint doi: https://doi.org/10.1101/2021.02.25.21252462; this version posted March 1, 2021. The copyright holder for this preprint (which was not certified by peer review) is the author/funder, who has granted medRxiv a license to display the preprint in perpetuity.

It is made available under a CC-BY-NC-ND 4.0 International license .

65 data using cell type-specific gene expression signatures derived from either microarray or scRNA-

66 seq reference ${ }^{12}$. Compared with biopsy samples in single cell analyses, tissue samples for bulk

67 analysis might better represent the original cell type compositions ${ }^{8,12}$.

68

69 For both single cell and bulk data, cell type proportions can be affected by various factors including

70 disease status and treatment effects. Consequently, the observed cell type proportion differences

71 between disease and healthy individuals might be the outcome of the disease and environmental

72 factors instead of disease causes.

73

74 Unlike assayed gene expression levels, genotypes are less likely to be affected by confounding

75 factors and reverse causation. The same idea underlies Mendelian randomization methods to infer

76 causal factors for different traits $9,10,14$. In this paper, we examined genetically regulated proportions

77 (GRPs) of cell types. We note that cell type proportions are heritable ${ }^{11,15}$, suggesting the feasibility

78 of inferring cell type proportions based on genotypes. Cell type proportions can vary substantially

79 in patients with different diseases ${ }^{16}$. We introduce a new framework, cell type Wide Association

80 Study (cWAS), to consider the GRPs of cell types as contributors to human disease. Through

81 simulation studies and real data analyses across 55 traits in 36 tissues, cWAS showed higher

82 statistical power in identifying disease-cell type proportion associations than typical cell-disease

83 association identification approaches like FUMA ${ }^{3}$. In summary, cWAS offers a novel way to

84 understand human diseases in a cell-type specific manner.

85 
medRxiv preprint doi: https://doi.org/10.1101/2021.02.25.21252462; this version posted March 1, 2021. The copyright holder for this preprint (which was not certified by peer review) is the author/funder, who has granted medRxiv a license to display the preprint in perpetuity.

It is made available under a CC-BY-NC-ND 4.0 International license .

\section{Results}

88 Model summary

89 We propose a statistical framework to identify cell types whose GRPs are associated with diseases.

90 The framework consists of two parts (Figure 1). First, under the assumption that there exist

91 signature genes signifying specific cell types (consistent with previous methods ${ }^{15,17}$ ), we infer

92 GRPs of cell types through deconvolution of the imputed tissue-specific gene expression levels

93 based on cis-SNP genotypes from eQTL data. Second, we combine the GRPs with disease

94 phenotype information to identify cell-type proportion associations with disease phenotypes.

96 In the first step, we build tissue-specific gene expression imputation models using the elastic net,

97 similar to previous Transcriptome-wide association study (TWAS) methods ${ }^{18-20}$. With the

98 imputation weights $\hat{\beta}_{g t}$, we obtain the estimation of genetically regulated tissue-level gene

99 expression for gene $g$ in tissue $t$ as $\hat{B}_{g t}=X_{g} \hat{\beta}_{g t}$, where $X_{g}$ is the genotype matrix of cis-SNPs

100 around gene $g$. With pre-obtained cell-type specific gene expression levels for signature genes, we

101 deconvolute the genetically imputed tissue-level expression data through the following model:

$$
\hat{B}_{t}=\hat{F}_{t} S_{t}^{T}
$$

103 where $S_{t} \in R^{G \times C}$ is the cell-type specific gene expression level matrix in tissue $t$ for $G$ signature

104 genes across $C$ cell types, $\widehat{F}_{t}$ is the estimated GRPs for all cell types in tissue $t$, and $\widehat{B}_{t}$ is the

105 imputed gene expression level matrix for all signature genes in tissue $t$. For a specific cell type $c$,

106 we assess its GRP association with phenotype $Y$ using the following model:

$$
Y=\hat{F}_{(., c), t} \gamma_{c}+\eta
$$

108 where $\gamma_{c}$ is the effect of GRP for cell type $c$ on the trait and $\eta$ is noise. $\widehat{F}_{(., c), t}$ is the estimated GRPs

109 of a cell type $c$, which is the $c$ th column of the $\hat{F}_{t}$ matrix. However, individual-level genotype data 
medRxiv preprint doi: https://doi.org/10.1101/2021.02.25.21252462; this version posted March 1, 2021. The copyright holder for this preprint (which was not certified by peer review) is the author/funder, who has granted medRxiv a license to display the preprint in perpetuity.

It is made available under a CC-BY-NC-ND 4.0 International license .

110 are not always available for GWAS, which makes the direct estimation of $\gamma_{c}$ from the above two-

111 step procedure unfeasible. With only summary statistics available, we propose to use the following

112 approach to assessing the association between GRPs of a cell type $c$ and traits

$$
z_{c} \approx \sum_{p} s e\left(X_{p}\right) z_{p} \hat{\beta}_{t p} S_{t}\left(S_{t}^{T} S_{t}\right)_{., c}^{-1} / s e\left(\hat{F}_{c}\right)
$$

114 where $\operatorname{se}\left(X_{p}\right)$ is the genotype standard deviation of SNP $p$, calculated from a reference panel; $z_{p}$

115 is the GWAS z score for SNP $p ; \hat{\beta}_{t p}$ is the imputed tissue-level gene expression vector of SNP $p$

116 across $G$ signature genes in tissue $t$, and (. $)_{., C}$ stands for the $c$ th column vector of the corresponding

117 matrix. cWAS takes the GWAS summary statistics as the input, which provides an indirect way

118 of estimating cell-type GRP associations with diseases that do not require individual-level data.

119 More model details are presented in the methods section, and the cWAS framework for GWAS

120 summary statistics is available at https://github.com/vivid-/cWAS.

\section{Simulation studies}

124 To evaluate cWAS performance in identifying cell type proportions associated with a disease, we

125 considered several simulation settings (Methods). We simulated disease phenotypes based on

126 genetically predicted proportions of M1 macrophages in whole blood, using 10,000 individuals

127 randomly sampled from UK Biobank ${ }^{21}$. Under moderate heritability settings, where genetic-

128 regulated cell type proportions explain $1 \%$ to $9 \%$ of the phenotype variances, cWAS had at least

$12998 \%$ power to identify M1 macrophages' association with the phenotype when all signature genes

130 were known and used (Figure 2a, the purple dashed line). Furthermore, M1 macrophage was

131 identified as the most significant cell type in at least $70 \%$ of 600 replicates (Figure $2 \mathbf{b}$ ) when 
medRxiv preprint doi: https://doi.org/10.1101/2021.02.25.21252462; this version posted March 1, 2021. The copyright holder for this preprint (which was not certified by peer review) is the author/funder, who has granted medRxiv a license to display the preprint in perpetuity.

It is made available under a CC-BY-NC-ND 4.0 International license .

132 heritability was 4\% or higher, and the effect of M1 macrophages identified by cWAS had the same

133 direction as that simulated in at least $90 \%$ of 600 replicates, while FUMA only identified

134 macrophages as the significant cell type in around 15\% of 600 replicates (S Table 1). When we

135 simulated phenotypes independent of cell type proportions in whole blood tissue, cWAS had a

136 well-controlled type I error rate (Figure 2c).

137

138 One critical point of cWAS is the reliability of cell type specific gene expression signatures. Many

139 cell-type deconvolution methods also depend on the accurate curation of the signature matrix, such

140 as those from microarray data of known cell types (like the LM22 matrix used in CIBERSORT ${ }^{17}$ ).

141 However, in many cases, we have to derive a signature matrix from single-cell data, which are

142 usually highly sparse and only include cell type-specific expression levels of a subset of signature

143 genes. Consequently, the signature genes curated from single-cell data may be incomplete

144 compared to those from more informative data sources, such as RNA-seq assayed in known cell

145 types. To evaluate the impact of incomplete genes in the signature matrix, we considered using a

146 subset (50\%-90\%) of signature genes in cWAS. When only half of the signature genes were used,

147 there was a significant drop in statistical power although the type I error was still well-controlled

148 (Figure 2d). With an increasing proportion of signature genes used, there was improved power in

149 identifying associated cell types (Figure 2a).

\section{Trait-tissue association patterns}

153 To further study disease-cell type proportion associations, we applied cWAS to GWAS summary 154 data from 55 traits (S Table 2, including autoimmune diseases, psychiatric disorders, and other 
medRxiv preprint doi: https://doi.org/10.1101/2021.02.25.21252462; this version posted March 1, 2021. The copyright holder for this preprint (which was not certified by peer review) is the author/funder, who has granted medRxiv a license to display the preprint in perpetuity.

It is made available under a CC-BY-NC-ND 4.0 International license .

155 traits like lipids and height) together with scRNA-seq data from the Human Cell Landscape

$156(\mathrm{HCL})^{22}$. We identified trait-associated cell types in 23 adult non-brain tissues and 13 fetal brain

157 tissues (S Table 3) using eQTLs for curated signature genes (Methods, S Fig. 1). Consistent with

158 findings from other methods, we found that the most significant cell types are usually present in

159 the trait-associated tissues ${ }^{1,23}$ (Figure 3a, S Fig. 2) supporting the validity of cWAS, e.g.,

160 oligodendrocytes from fetal brain amygdala for autism spectrum disorder (ASD) ( $\mathrm{p}=3.0 \mathrm{e}-3)$,

161 myeloid progenitor cells from whole blood for Crohn's disease ( $p=3.6 e-5)$, and endothelial cells

162 from a tibial artery for heart rate $(\mathrm{HR})(\mathrm{p}=4.0 \mathrm{e}-9)$. Several traits showed global cell type proportion

163 associations across multiple tissues, e.g., height and body mass index (BMI). This can be partly

164 explained by large sample sizes in BMI and height GWAS, as we also observed a significant

165 positive correlation $(\mathrm{p}=8.4 \mathrm{e}-4$, cor $=0.88)$ between the number of associated cell types and the

166 sample size of BMI and height GWAS when we down-sampled the GWAS results (Methods).

167 Notably, cWAS identified many cell type-trait associations in unexpected tissues. Many of them

168 are immune cells, for example, neutrophil cells in fetal brain frontal cortex are associated with

169 systemic lupus erythematosus (SLE) $(\mathrm{p}=5.8 \mathrm{e}-4)$, and macrophages from subcutaneous adipose and

170 neutrophils from the left ventricle of the heart are associated with anxiety disorders (ADIS)

$171 \quad(p=7.4 \mathrm{e}-3$ and 1.6e-3, respectively).

172

173 Since several cell types (S Table 4), especially immune cells, are present in multiple adult tissues,

174 we further investigated whether those identified disease-associated immune cell types above are

175 due to true biological process or false positives by studying tissue-tissue correlations based on

176 shared cell types' associations with traits (Methods). Compared to biologically unrelated tissue

177 pairs, the results showed a higher correlation among tissues with similar biological functions 
medRxiv preprint doi: https://doi.org/10.1101/2021.02.25.21252462; this version posted March 1, 2021. The copyright holder for this preprint (which was not certified by peer review) is the author/funder, who has granted medRxiv a license to display the preprint in perpetuity.

It is made available under a CC-BY-NC-ND 4.0 International license .

178 (Figure 3b), such as artery tissues (tibial artery, coronary artery, and aorta artery), heart tissues

179 (left heart ventricle and heart atrial appendage), and esophagus tissues (esophagus muscularis and

180 esophagus mucosa). This finding suggests that cell types are more likely to be identified as trait-

181 associated in disease-related tissues even though the same cell types may exist in multiple tissues.

183 We also evaluated correlations among traits based on their associations with different cell types

184 across 23 adult non-brain tissues and 13 fetal brain tissues, respectively (S Table 5). In 23 adult

185 non-brain tissues, we identified high correlations among many traits, e.g., autoimmune diseases

186 including eczema and SLE; lipid traits like total cholesterol (TC), low-density lipoprotein

187 cholesterol (LDL), and triglycerides (TG) (Figure 4a). Brain tissue associated traits have higher

188 correlations based on estimates using fetal brain tissues (Figure $4 \mathbf{b}$ ) compared to those from adult

189 non-brain tissues. For example, Alzheimer's disease (AD) is clustered with autoimmune-related

190 traits in adult non-brain tissues, whereas it is correlated with psychiatric traits like bipolar disorders

191 (BD) and ADHD in fetal brain tissues. For some other traits, their correlations in 13 fetal brain

192 tissues were similar to those identified in adult non-brain tissues. For example, a positive

193 correlation between ASD and ADHD was observed for both adult tissues $\left(R^{2}=0.33, \mathrm{p}=1.4 \mathrm{e}-7\right)$ and

194 fetal brain tissues $(0.55, \mathrm{p}=7.9 \mathrm{e}-16)$. Moreover, we observed correlations in different directions

195 between fetal brain tissues and adult non-brain tissues. For example, smoking initiation (SmkInit)

196 and asthma had a positive correlation in fetal brain tissues $(0.35, \mathrm{p}=1.1 \mathrm{e}-6)$ but a negative

197 correlation in adult non-brain tissues $(-0.33, \mathrm{p}=1.2 \mathrm{e}-7)$. The associations identified between asthma

198 and neuronal cells in fetal brain tissues may be supported by previous findings linking neural

199 pathways to allergic inflammation in lungs ${ }^{24,25}$. 
medRxiv preprint doi: https://doi.org/10.1101/2021.02.25.21252462; this version posted March 1, 2021. The copyright holder for this preprint (which was not certified by peer review) is the author/funder, who has granted medRxiv a license to display the preprint in perpetuity.

It is made available under a CC-BY-NC-ND 4.0 International license .

\section{Breast cancer and $\mathrm{CD8}^{+} \mathrm{T}$ cells}

203 To further examine the potential utility of cWAS using specific datasets, we applied cWAS to

204 identify cell types for breast cancer and two lung diseases. For breast cancer (BC), we used

205 European breast cancer GWAS summary data ${ }^{26}\left(\mathrm{n}=228,951, \mathrm{n} \_\right.$case $=122,977, \mathrm{n} \_$control=105,974).

206 In whole blood, we identified a significant negative association between GRPs of $\mathrm{CD}^{+} \mathrm{T}$ cells

207 and BC risk (Figure 5a) $(\mathrm{p}=8.9 \mathrm{e}-9)$ using the published signature gene expression matrix

208 LM22 $2^{12,17}$.

210 To explore potential biological and clinical implications of this result, we imputed genetic-

211 regulated cell type proportions in whole blood for subjects with European ancestry in The Cancer

212 Genome Atlas (TCGA) project who were diagnosed with BC (TCGA-BRCA) ${ }^{27}$ (see Methods).

213 We found that basal breast cancer patients with higher imputed $\mathrm{CD}^{+} \mathrm{T}$ cell proportions had an

214 overall better survival (Figure 5b, $\mathrm{p}=0.085)$. Results were similar but significant $(\mathrm{p}=0.034)$ for

215 luminal B breast cancer patients (Figure 5c). We also considered an alternative approach to

216 evaluating cell-type specific expression patterns of BC-associated genes identified using

217 epigenetic annotations and genetic signals $\left(\mathrm{T}-\mathrm{GEN}^{28}\right)$. BC-associated genes showed no significant

218 expression enrichment in any cell type of whole blood other than a significant depletion in dividing

219 NK T cells (fold-change=0.79, p=1.6e-8) (S Fig. 3a). Furthermore, BC-associated genes identified

220 by T-GEN did not show significantly higher expression levels in T cells or any other cell types (S

\section{Fig. 3b).}


medRxiv preprint doi: https://doi.org/10.1101/2021.02.25.21252462; this version posted March 1, 2021. The copyright holder for this preprint (which was not certified by peer review) is the author/funder, who has granted medRxiv a license to display the preprint in perpetuity.

It is made available under a CC-BY-NC-ND 4.0 International license .

223 To further validate the results, we studied BC-cell type proportion association using another cell

224 type proportion decomposition approach ${ }^{29}$. In this case, the cell type proportion association result

225 was based on the directly measured tumor tissue transcriptome data from TCGA-BRCA. We found

226 a similar protective effect of the $\mathrm{CD} 8^{+} \mathrm{T}$ cell proportion $(\mathrm{p}=0.013)$ in basal breast cancer patients

227 (S Fig. 4a), but not in luminal breast cancer patients (S Fig. 4b, 4c).

228

229

$230 \quad$ Lung diseases and lung tissue

231 Using single cell data ${ }^{30}$ with better quality than HCL data to identify cell types with small

232 proportions, we performed cWAS analysis for two lung diseases, idiopathic pulmonary fibrosis

233 (IPF, $\mathrm{n}=24,589, \mathrm{n} \_$case $=4,124, \mathrm{n} \_$control $\left.=20,465\right)^{31}$ and chronic obstructive pulmonary disease

$234\left(\mathrm{COPD}, \mathrm{n}=5,346, \mathrm{n} \_ \text {case }=2,812 \text {, n_control }=2,534\right)^{32}$. In IPF, a higher predicted proportion of

235 myofibroblast in lung tissue was associated with an increased risk of developing the disease

$236(p=5.3 e-4$, Figure 6a), consistent with the accumulation of myofibroblasts observed in IPF

237 patients $^{33}$. We also observed a negative association of fibroblast proportions in the development

238 of IPF ( $p=3.5 e-2)$, which is consistent with aberrant fibroblast-to-myofibroblast ${ }^{34}$ differentiation $^{2}$

239 and fibroblast degeneration and myofibroblast proliferation ${ }^{35}$ in IPF.

241 To further evaluate cell type associations with IPF, we investigated the cell type expression pattern

242 of IPF dysregulated genes by conventional transcriptomics analysis. Using differentially expressed

243 genes from the published ${ }^{36}$ RNA-seq data of lung tissue in IPF patients $(n=36)$ and non-disease

244 individuals $(\mathrm{n}=19)$, we found that upregulated genes in IPF patients were significantly enriched in

245 myofibroblasts (fold change $=1.3, \mathrm{p}=1.4 \mathrm{e}-3$, Figure 6b). However, genes differentially expressed 
medRxiv preprint doi: https://doi.org/10.1101/2021.02.25.21252462; this version posted March 1, 2021. The copyright holder for this preprint (which was not certified by peer review) is the author/funder, who has granted medRxiv a license to display the preprint in perpetuity.

It is made available under a CC-BY-NC-ND 4.0 International license .

in myofibroblasts can result either from genetic effects or disease status. We further analyzed the

247 cell type signal based on genetic information using IPF GWAS summary statistics. Applying MAGMA (implemented in FUMA, see URLs) to the IPF GWAS results (S Fig. 5a), we found marginal evidence of enriched genetic signals in the fibroblasts of lung tissue $(p=7.5 e-2)$. IPFassociated genes identified by $\mathrm{T}-\mathrm{GEN}^{37}$ did not show any significant enrichment in any cell type of lung. Therefore, though neither was significant after Bonferroni correction, both transcriptomic and gene-set based genetic analyses suggest the importance of myofibroblasts and fibroblasts consistent with cWAS.

For COPD, cWAS found higher GRPs of endothelial cells increased disease risk ( $\mathrm{p}=2.1 \mathrm{e}-4$, Figure sample size with a signature matrix having more refined cell types (Methods). One specific endothelial cell type, vascular endothelial capillary A, was positively associated $(p=3.9 e-4)$ with COPD based on results from another GWAS $(\mathrm{N}=257,811)^{38}$. Upregulated genes in COPD patient lung tissue ${ }^{36}$ were also enriched in endothelial cells (fold change $=1.4$, p-value $\left.=1.4 \mathrm{e}-2\right)($ Figure 6d). Similar to IPF analysis, we also investigated COPD genetic signal enrichment using MAGMA on mouse lung data (no human lung data available in FUMA, S Table 6). There was marginal

263 evidence of signal enrichment in endothelial cells in the lung tissue ( $p=8 \mathrm{e}-2, \mathbf{S}$ Fig. 5b) and lung

264 vasculature ( $p=2.8 \mathrm{e}-2$, S Fig. 5c). Similar to the results in IPF, T-GEN-identified genes in COPD 265 did not show any enrichment in cell types of lung. Nevertheless, these results support the cWAS results indicating a role for endothelial cells in COPD. 
medRxiv preprint doi: https://doi.org/10.1101/2021.02.25.21252462; this version posted March 1, 2021. The copyright holder for this preprint (which was not certified by peer review) is the author/funder, who has granted medRxiv a license to display the preprint in perpetuity.

It is made available under a CC-BY-NC-ND 4.0 International license .

269 We further validated the findings on IPF-myofibroblast and COPD-endothelial associations using

270 another lung scRNA-seq dataset ${ }^{30}$. This recent study profiled 32 IPF patients, 18 COPD patients,

271 and 28 controls, and we compared major cell type proportions across these three groups of samples

272 (S Fig. 6a). In IPF patients, the myofibroblast cell type proportion was significantly increased

$273(p=1.3 e-3$, Figure 7a) compared with other major cell types (Figure 7b). We also conducted

274 pathway analysis on both up- and down-regulated genes in IPF myofibroblast cells (Figure 7c).

275 The top enriched pathways of upregulated genes mostly function as the extracellular matrix ${ }^{39}$

276 (ECM), a network playing an important role in cell adhesion and linking glycoproteins with fibrous

277 proteins, supporting the importance of the fibroblast-to-myofibroblast migration process in IPF. In

278 COPD, despite low endothelial cell counts and the limited sample size in the single cell data (S

279 Fig 6b), analysis of upregulated genes in COPD endothelial cells (Figure 7d, S Fig 6b, 6c, 6d)

280 suggests the involvement of DNA-binding transcription activity and higher activity of COPD

281 endothelial cells compared to control endothelial cells.

282

283

284 Discussion

285 Recent analyses have devoted great efforts to understand GWAS findings in traits and diseases.

286 Several methods have been developed to link identified variants to genes based on genomic

287 locations ${ }^{2}$, epigenetic annotations, or eQTL regulations ${ }^{18}$. At the cell type or tissue level, methods

288 like LD score regression ${ }^{40}$ and $\mathrm{FUMA}^{3}$ either utilize annotation information or expression data to

289 investigate the genetic enrichment pattern in cell types or tissues. Differing from previous methods,

290 cWAS is a novel statistical framework to interpret GWAS findings in a cell type proportion manner.

291 It helps researchers gain insights into the relationship between cell type GRPs and diseases. cWAS 
medRxiv preprint doi: https://doi.org/10.1101/2021.02.25.21252462; this version posted March 1, 2021. The copyright holder for this preprint (which was not certified by peer review) is the author/funder, who has granted medRxiv a license to display the preprint in perpetuity.

It is made available under a CC-BY-NC-ND 4.0 International license .

292 is complementary to cell type-disease associations identified solely through genetic association or

293 heritability enrichment, especially when genetic signals are mediated by regulating cell type

294 proportions. Identified disease-associated cell type proportions can potentially serve as biological

295 markers in clinical practices to identify patients with higher genetic risk ${ }^{41,42}$. Applying cWAS to

296 GWAS summary statistics from 55 traits, we found that previously genetically correlated traits

297 also have correlated associations with GRPs of cell types. Applications of cWAS to Breast Cancer,

298 IPF, and COPD identified cell type proportion-trait associations, which were supported by either

299 previous findings or our analysis of other data. Specifically, a high proportion of $\mathrm{CD} 8^{+} \mathrm{T}$ cells was

300 identified as protective in breast cancer development based on both transcriptome and cWAS

301 analyses. Survival analysis using imputed GRPs of cell types also implied a protective effect of

302 higher $\mathrm{CD}^{+} \mathrm{T}$ cell proportion in breast cancer prognosis. All these findings support the importance

303 of $\mathrm{CD}^{+} \mathrm{T}$ cell proportions for both disease onset and prognosis in breast cancer.

305 We noted that transcriptome analyses of breast cancer patients have also identified the importance

306 of $\mathrm{CD}^{+} \mathrm{T}$ cells. Utilizing breast tumor infiltration data, multiple published survival studies ${ }^{43,44}$

307 found protective effects of high $\mathrm{CD}^{+} \mathrm{T}$ cell proportions in the tumor tissue for breast cancer. In

308 contrast to TCGA results based on observed breast tissue expression data, cWAS identifies

309 genetically regulated cell type proportions in whole blood, which are more likely to cause the

310 development of the disease instead of being affected by the disease status. Although the

311 mechanisms in the prognosis and the development of breast cancer are not necessarily the same,

312 the converging evidence from different approaches used here suggests the importance of CD8 ${ }^{+} \mathrm{T}$

313 cells in breast cancer. 
medRxiv preprint doi: https://doi.org/10.1101/2021.02.25.21252462; this version posted March 1, 2021. The copyright holder for this preprint (which was not certified by peer review) is the author/funder, who has granted medRxiv a license to display the preprint in perpetuity.

It is made available under a CC-BY-NC-ND 4.0 International license .

315 We also note that previous COPD research has already implied the importance of endothelial

316 cells $^{45}$, which are involved in both the initiation and progression of COPD as well as other lung

317 diseases, such as asthma and emphysema. More specifically, endothelial cells play a role in the

318 transendothelial migration (TEM), through which neutrophils move to lung tissue and respond to

319 the residential inflammation ${ }^{46}$. Additionally, endothelial apoptosis in lung initiates and contributes

320 to the progression of COPD disease ${ }^{45,47}$. Previous genetic research also identified the importance

321 of endothelial cells in $\mathrm{COPD}^{38}$ using ATAC-seq data and emphysema ${ }^{48}$. This further lends support

322 to the involvement of endothelial cells in developing COPD.

324 Similar to many statistical methods, cWAS is also highly dependent on the data used, more

325 specifically, the single cell data. The single cell data used in signature gene expression curation

326 can affect $\mathrm{cWAS}$ performance, including the cell types included and the signature gene expression

327 levels. More single cell databases with larger sample sizes, higher resolution and more comparable

328 experiment pipelines across more tissues will aid in its further application and result interpretation.

329 To mitigate the batch effects across various tissues, for trait-trait correlation analysis and multi-

330 tissue association analysis, we used the HCL dataset to extract signature gene matrices since the

331 test results will be comparable across tissues due to relatively small batch effects and the same cell

332 labeling criteria in all tissues. For BC, we used the LM22 matrix, which was curated based on the

333 Affymetrix microarray data, to extract the signature matrix in whole blood. In IPF and COPD, the

334 signature matrix was curated using single cell data of lung from HCL, which consists of 23,878

335 cells from 20 cell types. Notably, due to randomness of obtaining samples in experiments, cell

336 type composition in lung single cell data can be strongly biased, with $90 \%$ of the cells being 337 immune cells. Despite this limitation, we identified a non-immune cell population in COPD. Our 
medRxiv preprint doi: https://doi.org/10.1101/2021.02.25.21252462; this version posted March 1, 2021. The copyright holder for this preprint (which was not certified by peer review) is the author/funder, who has granted medRxiv a license to display the preprint in perpetuity.

It is made available under a CC-BY-NC-ND 4.0 International license .

results based on fetal brain single cell data relied on the assumption that the genetic regulation of gene expression is the same in both adult and fetal tissues. The assumption could be violated for tissues still undergoing development in fetuses ${ }^{49}$. The accuracy of cWAS results could be further improved if matched genotype and cell type proportion data were available for identifying cell type proportion QTLs.

Nevertheless, future work can further expand the potential of cWAS analysis. First, considering the differentiation trajectory between cell types will further better pinpoint the associated cell types or even causal cell types, but will also limit the application of cWAS since not all differentiation trajectories are known in human tissues. Second, when analyzing specific traits across tissues to identify the most signal-enriched tissue, we found that traits like BMI and height are associated with cell types in almost all tissues, even though both BMI $(\mathrm{p}=1.4 \mathrm{e}-13)$ and height $(\mathrm{p}<2 \mathrm{e}-16)$ has the strongest signal in whole blood tissue. The results can be affected by the comparably large sample size of BMI and height GWAS as well as the complex biological processes involved in these traits. Future work can explore the potential of jointly modeling multiple traits to identify trait-specific associations with cell type proportions.

To conclude, different from bulk RNA-seq or scRNA-seq analysis comparing patients and healthy individuals, cWAS assesses the association between GRPs of cell types and diseases. In addition to typical genetic enrichment methods like MAGMA and LD score regression, cWAS provides a novel way to investigate the cell type-disease association. Both simulation and real data analyses have demonstrated the statistical power of cWAS in providing new insights in understanding the genetic etiology of human diseases from the cell type proportion perspective. 
medRxiv preprint doi: https://doi.org/10.1101/2021.02.25.21252462; this version posted March 1, 2021. The copyright holder for this preprint (which was not certified by peer review) is the author/funder, who has granted medRxiv a license to display the preprint in perpetuity.

It is made available under a CC-BY-NC-ND 4.0 International license .

\section{Online Methods}

\section{Expression imputation model training}

364 Tissue-specific expression imputation models were trained in 44 tissues using matched individual-

365 level RNA-seq and whole-genome sequencing data from the GTEx (v8) project. We focused on

366 common SNPs (minor allele frequencies $>0.05$ ) by filtering out SNPs whose allele frequencies

367 were smaller than 0.05. RNA-seq data were adjusted for possible confounding factors, including

368 the first five genotype principal components (PCs) and different numbers of Probabilistic

369 Estimation of Expression Residuals (PEER) factors. Only cis-SNPs located within 1Mb from the

370 transcription starting site of each gene were considered for training the gene expression imputation

371 model.

372

373 Ten-fold cross-validated elastic-net models were applied to build gene expression imputation

374 models, with the parameter $\alpha$ as 0.5 and the optimal $\lambda$ selected via the function cv.glmnet provided

375 in the 'glmnet' package. Only gene expression imputation models with FDR $<0.05$ were

376 considered in the following analysis. To make the test results more robust, we only considered

377 those models with an imputation accuracy higher than the median level in each tissue.

\section{Single cell datasets preprocessing}

381 All single-cell data used in this project were obtained from public repositories. In the trait

382 association analysis, we obtained the tissue-specific signature matrices from the Human Cell

383 Landscape $(\mathrm{HCL})^{22}$, sequenced on the microwell-seq platform [1]. HCL provides a coherent

384 sequencing procedure that can minimize the batch-effects to have a higher consistency, making 
medRxiv preprint doi: https://doi.org/10.1101/2021.02.25.21252462; this version posted March 1, 2021. The copyright holder for this preprint (which was not certified by peer review) is the author/funder, who has granted medRxiv a license to display the preprint in perpetuity.

It is made available under a CC-BY-NC-ND 4.0 International license .

385 the trait-trait correlation analysis feasible. To better utilize HCL, we manually cleaned the cell type

386 annotation across the tissues to have a consistent cell type naming rule.

388 We found that the curation of signature matrices might not be representative enough if they were

389 only based on the raw counts due to the high drop-out rate of single cell data. To alleviate this

390 problem, We applied SAVERX ${ }^{50}$, a deep Bayesian autoencoder single cell imputation tool

391 implemented with transfer learning, on the single cell expression profile to impute drop-out events

392 before signature matrix computation. SAVERX may distinguish the dropout and real zero

393 expression, which helps to get a more accurate cell type-specific average expression. It is common

394 when some single cell datasets have a rare cell population. The limited cell counts make the

395 average expression profile across cells unstable for signature matrix. Therefore, we filtered out

396 cell types with low counts and only kept the major cell types.

397

398 In lung disease analysis, to get the signature matrix with deeper sequencing depth and accurate 399 cell type annotations, we used control samples in the IPF cell atlas, which contains 312,928 cells

400 from subjects without IPF and without IPF. We partitioned the lung atlas randomly to get a smaller

401 subset with 20,000 cells. For the signature matrix with more cell types, we include all observed

402 cell types, while the signature matrix curated for the original two GWAS summary stats only

403 included the main 20 cell types annotated in the IPF cell atlas. 
medRxiv preprint doi: https://doi.org/10.1101/2021.02.25.21252462; this version posted March 1, 2021. The copyright holder for this preprint (which was not certified by peer review) is the author/funder, who has granted medRxiv a license to display the preprint in perpetuity.

It is made available under a CC-BY-NC-ND 4.0 International license .

407 After getting SNP weights $\hat{\beta}_{t}$ on the tissue-specific gene expression imputation models, we further

408 combined them with published GWAS summary statistics to estimate cell-type associations with

409 disease phenotypes. For a specific cell type $c$, we consider the association between a phenotype $Y$

410 and its genetically regulated cell type proportions $\hat{F}_{c}$ as $Y=\widehat{F}_{(., c), t} \gamma_{c}+\eta$. From the linear

411 deconvolution of genetically imputed tissue-specific gene expression, we can estimate the

412 genetically regulated cell type proportion as follows:

$$
\hat{F}_{t}=\hat{B}_{t} S_{t}\left(S_{t}^{T} S_{t}\right)^{-1}=X \hat{\beta}_{t} S_{t}\left(S_{t}^{T} S_{t}\right)^{-1}
$$

414 where $\widehat{F}_{t}$ is the cell type proportion matrix in tissue $t$ and $S_{t}$ is the expression matrix of cell-type

415 specific signature genes.

417 When the individual level data are not available, we cannot obtain the cell proportions $\widehat{F}_{c}$. By 418 considering the genotype-phenotype association $Y=X \omega+\eta_{1}$, we can indirectly estimate the 419 coefficient $\gamma_{c}$ as follows:

$$
\begin{gathered}
\hat{\gamma}_{c}=\frac{\operatorname{cov}\left(Y, \hat{F}_{(., c), t}\right)}{\operatorname{var}\left(\hat{F}_{(., c), t}\right)}=\frac{\operatorname{cov}\left(X \omega+\eta_{1}, X \hat{\beta}_{t} S_{t}\left(S_{t}^{T} S_{t}\right)^{-1}\right)}{\operatorname{var}\left(\hat{F}_{(., c), t}\right)} \\
=\sum_{p} \frac{\operatorname{var}\left(X_{p}\right) \omega_{p} M_{c, p}}{\operatorname{var}\left(\hat{F}_{(., c), t}\right)}
\end{gathered}
$$

where $M_{c}=\hat{\beta}_{t} S_{t} A_{c}$ and $A=\left(S_{t}^{T} S_{t}\right)^{-1}$.

424 To further get the z-score statistics for each cell type $z_{c}=\frac{\widehat{\gamma}_{c}}{\operatorname{se}\left(\widehat{\gamma}_{c}\right)}$, we would need to get the variance

of the estimated coefficients $\hat{\gamma}_{c}$. Based on simple linear regression, we can get:

$$
\operatorname{var}\left(\hat{\gamma}_{c}\right)=\frac{\operatorname{var}(\eta)}{n \times \operatorname{var}\left(\hat{F}_{(., c), t}\right)}=\frac{\operatorname{var}(Y)\left(1-R_{c}^{2}\right)}{n \times \operatorname{var}\left(\hat{F}_{(., c), t}\right)}
$$


medRxiv preprint doi: https://doi.org/10.1101/2021.02.25.21252462; this version posted March 1, 2021. The copyright holder for this preprint (which was not certified by peer review) is the author/funder, who has granted medRxiv a license to display the preprint in perpetuity.

It is made available under a CC-BY-NC-ND 4.0 International license .

427 where $R_{c}^{2}$ is the correlation between the phenotype $Y$ and the predictor $\hat{F}_{(., c), t}$. At the same time,

428 based on the phenotype-genotype association from GWAS, we would have:

$$
\operatorname{var}\left(\omega_{p}\right)=\frac{\operatorname{var}(Y)\left(1-R_{p}^{2}\right)}{n \times \operatorname{var}\left(X_{p}\right)}
$$

430 where $R_{p}^{2}$ is the correlation between the phenotype $Y$ and the predictor $\hat{X}_{p}$. Combining the 431 equations above, we can get the $z_{c}$ statistic formulated as follows:

$$
\begin{aligned}
z_{c} & =\sum_{p} \frac{\operatorname{var}\left(X_{p}\right) \omega_{p} M_{c, p}}{\operatorname{var}\left(\hat{F}_{c}\right)} / \operatorname{se}\left(\hat{\gamma}_{c}\right) \\
& \approx \sum_{p} \operatorname{se}\left(X_{p}\right) z_{p} M_{c, p} / \operatorname{se}\left(\hat{\gamma}_{c}\right)
\end{aligned}
$$

and $z_{p}$ is the z-score for SNP $p$ for GWAS summary stats for the phenotype of interest.

\section{Simulation}

438 In simulation studies, we randomly sampled 10,000 individuals from the UK Biobank dataset.

439 Based on their genotypes of common SNPs and gene expression imputation weights trained above,

440 we imputed their genetically regulated gene expression levels in whole blood and lung. Based on

441 the LM22 signature matrix and simple linear regression, we imputed the cell type proportions for

442 each sample in whole blood and used the signature matrix curated from the HCL database to get

443 the cell proportion for lung tissue. For power analysis, we simulated phenotypes based on the

444 imputed cell type proportion of M1 macrophages under different cis-eQTL heritability values from

4450.01 to 0.09 by assuming the effect size of each cis-SNP follows the same normal distribution.

446 Here we defined the heritability as the phenotypic variance contributed by the imputed cell type

447 proportion of M1 macrophages. Then we used PLINK to conduct GWAS analysis to obtain the 
medRxiv preprint doi: https://doi.org/10.1101/2021.02.25.21252462; this version posted March 1, 2021. The copyright holder for this preprint (which was not certified by peer review) is the author/funder, who has granted medRxiv a license to display the preprint in perpetuity.

It is made available under a CC-BY-NC-ND 4.0 International license .

448 GWAS summary results. Sex and first ten principal components of genotypes were adjusted. These

449 GWAS summary results were used in the cWAS test to identify disease-cell type proportion

450 association in whole blood. For the type-I error analysis, the disease phenotypes were simulated

451 based on imputed proportions of basal cells in lung tissue. Similar to the analysis in the whole

452 blood tissue, we obtained the GWAS summary statistics but the heritability we considered was

$4530.05,0.1$, and 0.5 . After getting the GWAS results, we applied cWAS to identify disease-cell type

454 proportion associations in whole blood tissue.

455

456

457 Signature gene expression matrix curation

458 Only protein-coding genes were considered here. We selected the signature genes by differential 459 expression (DE) analysis, i.e., Wilcoxon rank sum test, Model-based Analysis of Single-cell

460 Transcriptomics (MAST) ${ }^{51}$, and ANOVA. Among these methods, MAST is a DE framework that

461 takes cell size and drop-out rates into consideration. The Wilcoxon Rank Sum test and MAST for

462 DE analysis were conducted by the FindMarkers() command in package Seurat (3.1.5). Bonferroni

463 correction at $\alpha=0.05$ was used. When a large number of DE genes were selected, we kept the DE

464 genes which were upregulated and differential to a single cell population. We took the intersection

465 between significant DE genes and the GTEx-V8 genes of the corresponding tissue and included

466 them in the signature matrix. By setting different thresholds and applying appropriate DE analysis

467 approaches for filtering, we aimed to get the signature matrices. We computed the cell type-

468 specific gene signature matrices by the average expression levels across cells within cell

469 populations in the final step.

470 
medRxiv preprint doi: https://doi.org/10.1101/2021.02.25.21252462; this version posted March 1, 2021. The copyright holder for this preprint (which was not certified by peer review) is the author/funder, who has granted medRxiv a license to display the preprint in perpetuity.

It is made available under a CC-BY-NC-ND 4.0 International license .

\section{Survival analysis in TCGA data}

473 The imputation of the tissue-specific bulk RNA-seq expression for the TCGA-BRCA samples was

474 based on individual germline genotypes and corresponding expression weights trained above. We

475 followed the same procedure in the work of Huang et al. to process the germline genotypes ${ }^{27}$ from

476 TCGA. Missing SNPs were not considered.

After getting the imputed tissue-level gene expression, we used linear regression to estimate the genetically regulated cell type proportions for each sample. For survival analysis, we compared the disease-free survival times between groups with a high and lower percentage of genetically predicted cell type proportion of the identified cell type. More specifically, we extracted those two groups of samples with extremely high (e.g.: top 10\%) or low genetically predicted cell type proportion levels. Then, we compared disease-free survival times for the samples with the top percentage of genetically regulated cell type proportion and those with a lower percentage of genetically regulated cell type proportion levels.

\section{Curation of GWAS summary data}

489 We collected GWAS summary data of 55 phenotypes, their detailed information can be found in

490 supplementary table 2 . We intentionally selected studies with most of the populations being 491 European to reduce the bias due to population stratification. GWAS summary statistics were 492 curated by first filtering out SNPs with minor allele frequencies less than 0.05 . For datasets without 493 rsID, we used the human genome reference build 37 to map to corresponding rsID. For datasets 
medRxiv preprint doi: https://doi.org/10.1101/2021.02.25.21252462; this version posted March 1, 2021. The copyright holder for this preprint (which was not certified by peer review) is the author/funder, who has granted medRxiv a license to display the preprint in perpetuity.

It is made available under a CC-BY-NC-ND 4.0 International license .

494 without Z score or P-value, we manually obtained those columns using other available information

495 such as beta, odds ratio, and standard error. After these steps, all GWAS summary statistics contain

496 rsID, reference and alternative alleles, $\mathrm{Z}$ scores, $\mathrm{p}$ values, and sample sizes.

498 For down-sampled GWAS summary stats, we considered the $\mathrm{z}$ scores as $z=\sqrt{n} \beta$, where $\beta$ is the 499 reported effect sizes in GWAS results and $n$ is the sample size. When we reduced the sample size

500 of the GWAS summary stats, we consider the $z_{\text {downsample }}=\frac{z_{\text {original }}}{\sqrt{R}}$, where $R$ is the ratio of the 501 sample size in the original GWAS summary stats over the sample size in the down sampled GWAS 502 summary stats. We considered $R=2,3,4,5$ in our study here.

\section{MAGMA}

506 To generate annotations, gene location files using the human genome reference panel build 37 507 were downloaded from the MAGMA software website as the input of the gene location file. The 508 SNP location file was generated by extracting SNPs from curated GWAS summary data and 509 mapping to genome locations using build 37. Annotations were generated with the command: 510 magma --annotate --snp-loc [SNPLOC_FILE] --gene-loc [GENELOC_FILE] --out 511 [ANNOT_PREFIX].

512 Next, gene analysis was performed for each phenotype using the annotation files generated from 513 the previous step. European panels of the 1000 Genomes phase 3 data downloaded from the

514 MAGMA software website were used as the reference. The following command was used to 515 generate gene analysis results: magma --bfile [REFDATA] --gene-annot 516 [ANNOT_PREFIX].genes.annot --pval [PVAL_FILE] ncol=N snp-id=SNP pval=P --out 
medRxiv preprint doi: https://doi.org/10.1101/2021.02.25.21252462; this version posted March 1, 2021. The copyright holder for this preprint (which was not certified by peer review) is the author/funder, who has granted medRxiv a license to display the preprint in perpetuity.

It is made available under a CC-BY-NC-ND 4.0 International license .

517 [GENE_PREFIX]. Finally, 161 processed single cell expression datasets provided by MAGMA

518 were downloaded. To avoid duplicated cell types in multiple datasets from the same data resource,

519 we manually selected 60 datasets (S Table 6) for the following analysis. MAGMA gene-property

520 analyses (v1.07) were performed using the output of gene analysis and gene expression datasets

521 processed as described above using the following command: magma --gene-results

522 [GENE_PREFIX].genes.raw --gene-covar [SCDATA] --model condition-hide=Average

523 direction=greater --out [OUT_PREFIX]. Bonferroni corrections were performed per dataset

524 during the gene-property analyses to obtain significantly associated cell types.

527 Trait-cell type association analysis across tissues

528 Using the signature gene matrix processed from the HCL database, we applied cWAS to obtain

529 cell type association results for each trait across different tissues. To investigate trait-trait

530 correlation, we considered the test-statistics ( $\mathrm{z}$ scores) of all cell types in a trait as the

531 representation vector of the trait. Then for any two traits, we computed the Pearson correlation

532 between their two $\mathrm{z}$ score vectors and the corresponding $\mathrm{p}$-value to quantify the similarity between

533 these two traits with respect to cell type associations. Similarly, to consider the correlation of the

534 effects of a shared cell type between tissues, for a specific cell type, we would treat its association

$535 \mathrm{z}$ scores with all traits in one tissue as a vector $v_{1}$. We then put its association $\mathrm{z}$ scores with all

536 traits in a second tissue as a vector $v_{2}$. To study the tissue-tissue correlation for the shared cell type

537 effects, we calculated the Pearson correlation between $v_{1}$ and $v_{2}$. 
medRxiv preprint doi: https://doi.org/10.1101/2021.02.25.21252462; this version posted March 1, 2021. The copyright holder for this preprint (which was not certified by peer review) is the author/funder, who has granted medRxiv a license to display the preprint in perpetuity.

It is made available under a CC-BY-NC-ND 4.0 International license .

539 In the across-tissue analysis, for each trait, we firstly identified the significant cell type associations

540 after the Bonferroni correction in each tissue. Then across all tissues, we identified the most

541 significant cell type association signals.

544 Differentially expressed genes from bulk and cell type enrichment analysis

545 Differentially expressed (DE) genes in IPF and COPD patients were downloaded from previous

546 publications ${ }^{36,52}$. We curated the cell-type specific gene expression matrix in lung tissue using the 547 published single cell data. Then for each gene, we identified the cell type with the highest 548 expression. Then for each cell type, we analyzed the enrichment pattern of upregulated genes in 549 patients compared to other genes in the cell type. The binomial test was used to test the significance 550 level of the enrichment pattern and then Bonferroni correction was further applied to select the 551 significant cell types.

552

553 The Gene Set Enrichment Analysis was conducted by the gseGO() command in package clusterProfiler 554 (3.14.3). All the parameters were set to the defaults values, where Benjamin-Hochberg correction at $555 \alpha=0.05$ was used as the cutoff.

558 URLs:

559 Human cell landscape: http://bis.zju.edu.cn/HCL/

560 GTEx data: https://gtexportal.org/home/

561 Roadmap Epigenomics project: https://egg2.wustl.edu/roadmap/web_portal/ 
medRxiv preprint doi: https://doi.org/10.1101/2021.02.25.21252462; this version posted March 1, 2021. The copyright holder for this preprint (which was not certified by peer review) is the author/funder, who has granted medRxiv a license to display the preprint in perpetuity.

It is made available under a CC-BY-NC-ND 4.0 International license .

562 BC summary stats: http://bcac.ccge.medschl.cam.ac.uk/

563 COPD summary stats: https://pubmed.ncbi.nlm.nih.gov/24621683/;

564 https://pubmed.ncbi.nlm.nih.gov/30804561/

565 IPF summary stats: https://github.com/genomicsITER/PFgenetics

566 MAGMA: https://github.com/Kyoko-wtnb/FUMA_scRNA_data

569 Acknowledgements

570 Part of the this work was supported by funding from NIH grant R01GM134005 and NSF grant

571 DMS1902903 to H.Z., NHLBI grants R01HL127349, R01HL141852, U01HL145567,

572 UH2HL123886 to N.L. and a generous gift from Three Lakes Partners to N.K. M.H.C. was

573 supported by R01HL135142, R01 HL137927, R01 HL089856, R01 HL147148. The research was

574 partially supported by the NIHR Leicester Biomedical Research Centre; the views expressed are

575 those of the authors and not necessarily those of the NHS, the NIHR or the Department of Health.

576

577

578 Conflicts of Interest

579 N.K. served as a consultant to Boehringer Ingelheim, Third Rock, Pliant, Samumed, NuMedii,

580 Theravance, LifeMax, Three Lake Partners, Optikira, Astra Zeneca, Augmanity over the last 3

581 years, reports Equity in Pliant and a grant from Veracyte and Boehringer Ingelheim and non-

582 financial support from MiRagen and Astra Zeneca. N.K. as IP on novel biomarkers and 583 therapeutics in IPF licensed to Biotech. M.H.C. has received grant support from GSK and Bayer, 
medRxiv preprint doi: https://doi.org/10.1101/2021.02.25.21252462; this version posted March 1, 2021. The copyright holder for this preprint (which was not certified by peer review) is the author/funder, who has granted medRxiv a license to display the preprint in perpetuity.

It is made available under a CC-BY-NC-ND 4.0 International license .

584 consulting or speaking fees from Genentech, AstraZeneca, and Illumina. L.V.M. holds a

585 GSK/British Lung Foundation Chair in Respiratory Research.

586

587 Author Contributions

588 W.L., W.D. and M.C. developed the statistical framework.

589 W.L., W.D. and M.C. performed statistical analysis.

590 Z.D. assisted in analyzing single cell data.

591 B.Z. performed pathway enrichment analysis.

592 Y.Z. assisted in analyzing GTEx data.

593 D.T. analyzed the TCGA infiltration data and cell type proportional analysis.

594 M.S., L.V.W., M.H.C., N.K., and H.Z. advised on the biology of lung diseases.

595 H.Z. advised on statistical and genetic analysis.

596 W.L. implemented the software.

597 W.L., W.D. and M.C. wrote the manuscript.

598 All authors contributed to manuscript editing and approved the manuscript.

601 Figure Legends:

602 Figure 1. The schematic framework of cWAS

603 Bulk gene expression levels are firstly imputed based on each individual's genotypes. Combined

604 with a signature gene expression matrix for different cell types, imputed gene expression data for 605 each tissue are used to infer cell type compositions. Comparing different genetically inferred cell 
medRxiv preprint doi: https://doi.org/10.1101/2021.02.25.21252462; this version posted March 1, 2021. The copyright holder for this preprint (which was not certified by peer review) is the author/funder, who has granted medRxiv a license to display the preprint in perpetuity.

It is made available under a CC-BY-NC-ND 4.0 International license .

606 type compositions in case and control groups, cWAS can identify cell types whose genetic-

607 regulated proportions are associated with a trait of interest.

608 Figure 2. High power of cWAS in simulation studies with a controlled type I error rate

609 Different colors indicate different proportions $(0.5,0.7,0.9$, and 1$)$ of signature genes used in the

$610 \mathrm{cWAS}$ test. The phenotypic variance explained by the genetically regulated cell type proportions

611 (M1 macrophages) ranges from 0.01 to 0.09 for panels $\mathrm{A}$ and B, respectively. a) Each line

612 represents the percentage of simulations where cWAS identified the M1 macrophages as

613 associated with simulated phenotypes. b) This figure shows the proportion of times that the M1

614 macrophage was identified as the most significant cell type whose proportion was associated with

615 simulated phenotypes. The line represents the rate (top selection rate) under settings with different

616 proportions of known signature genes. For panels $\mathrm{c}$ and d, we simulated phenotypes based on the

617 genetic-regulated proportion of basal cells in lung tissue with heritability being $0.05,0.1$, or 0.5 .

618 c) All signature genes in whole blood are known when conducting the cWAS test. The red dashed

619 line indicates the 5\% type I error. The green line indicates the proportion of simulations where any

620 cell type in whole blood was selected as associated with the simulated disease status, the orange

621 line indicates the proportion of simulations where M1 macrophages were selected as associated

622 with the simulated disease. d) Only $50 \%$ of signature genes in whole blood are known.

\section{Figure 3. Disease-cell type associations in multiple tissues}

624 a) Across 12 tissues, the $\mathrm{z}$ scores derived from the test statistics quantify the associations between

625 genetically regulated cell type proportions and diseases. If there is no cell type significantly

626 associated with a disease after Bonferroni correction, the corresponding entry is blank. The number

627 in each block indicates the p-value of the most significant association between the cell type

628 proportion of the corresponding tissue and the disease. HOMA-B: beta-cell function; SLE: 
medRxiv preprint doi: https://doi.org/10.1101/2021.02.25.21252462; this version posted March 1, 2021. The copyright holder for this preprint (which was not certified by peer review) is the author/funder, who has granted medRxiv a license to display the preprint in perpetuity.

It is made available under a CC-BY-NC-ND 4.0 International license .

629 Systemic Lupus Erythematosus; Crohn: Crohn's disease; IBD: Inflammatory Bowel Disease;

630 CAD: Coronary Artery Disease; FG: Fasting Glucose; LDL: LDL cholesterol; PSC: Primary

631 Sclerosing Cholangitis; PBC: Primary Biliary Cirrhosis; HR: Resting Heart Rate; TC: Total

632 Cholesterol; TG: Triglycerides; MDD: Major Depressive Disorder; ADs: Anxiety Disorder;

633 Height: Height; ASD: Autism Spectrum Disorder; BD: Bipolar Disorder; BMI: Body Mass Index;

634 DrnkWk: Drinks per Week. b) For any tissue pair, we only considered shared cell types and treated

635 their proportion associations across 55 tissues. Tissue-tissue correlations were calculated based on

636 the cell type-disease associations for the shared cell types. The darker color indicates a higher

637 significance level.

638 Figure 4. Trait-trait correlation

639 Different colors indicate the correlation level and the stars indicate the significant correlations after

640 Bonferroni correction. a) Trait-trait correlation calculated from cell-disease associations in adult

641 non-brain tissues. b) Trait-trait correlation based on cell-disease associations in fetal brain tissues.

642 Figure 5. $\mathrm{CD8}^{+} \mathbf{T}$ cells in breast cancer

643 a) cWAS results of breast cancer in whole blood. The $x$ axis is the $z$ score of the cell type-disease

644 association from cWAS. Negative z scores indicate negative associations between cell type

645 proportions and diseases. The red line indicates the significance threshold (0.05) after Bonferroni

646 correction. The star indicates significant cell types after Bonferroni correction. b) and c) show

647 survival analysis results in breast cancer patients of TCGA. B) Considering the white basal patients

648 with top $10 \%$ and low $10 \%$ of genetically regulated cell type proportions of $\mathrm{CD}^{+} \mathrm{T}$ cells, and the

649 survival patterns were compared between patients in these two groups. c) shows the results of a

650 similar analysis in white Luminal B breast cancer patients considering patients with top $40 \%$ and

651 bottom $40 \%$ of GRPs of $\mathrm{CD}^{+} \mathrm{T}$ cells. 
medRxiv preprint doi: https://doi.org/10.1101/2021.02.25.21252462; this version posted March 1, 2021. The copyright holder for this preprint (which was not certified by peer review) is the author/funder, who has granted medRxiv a license to display the preprint in perpetuity.

It is made available under a CC-BY-NC-ND 4.0 International license .

652 Figure 6. cWAS association results of IPF and COPD in lung

653 For a) and c), the red line indicates the significance threshold (0.05) after Bonferroni correction.

654 For all figures, stars indicate significant cell types after Bonferroni correction. a) cWAS results of

655 IPF in lung tissue. The $\mathrm{x}$ axis is the $\mathrm{z}$ score of the cell type-disease association from cWAS.

656 Negative $\mathrm{z}$ scores indicate a negative association between cell type proportions and the disease. b)

657 Cell-type specific expression enrichment pattern of upregulated genes in IPF patients. c) cWAS

658 results of COPD in lung tissue. d) Cell-type specific expression enrichment pattern of upregulated

659 genes in COPD patients.

660 Figure 7. IPF myofibroblast and COPD endothelial cell type proportion validation in the

661 separate scRNA-seq atlas.

662 a) Boxplots of myofibroblast cell type proportions in 32 IPF patients and 28 controls. The vertical

663 axis is the cell type proportion of myofibroblast. The IPF myofibroblast cell proportion is

664 significantly higher than that in controls with $\mathrm{p}$-value $=1.3 \mathrm{e}-3$ by t-test. b) Bar plots of $\mathrm{z}$ scores

665 when cell type proportions were regressed on conditions of IPF and control. The red line indicates

666 the significance threshold (0.05) after the Bonferroni correction. The star indicates the significant

667 cell types after Bonferroni correlation. All the cell types with z scores greater than 2 are labeled

668 with an asterisk. Only cell types whose proportions are more than $1 \%$ are shown. Myofibroblast

669 ranks second in these 15 major cell populations. This difference may be related to the genetically

670 mediated regulation of cell type proportion based on the cWAS results. c) Scatterplots of Gene Set

671 Enrichment Analysis (GSEA) results of IPF myofibroblast up-regulated genes. The dot size is the

672 gene counts found in the pathway. The colors indicate the hypergeometric test p-values. Most top

673 enriched pathways are related to ECM and cell adhesion. d) Scatterplots of GSEA results on COPD

674 endothelial up-regulated genes. The dot size is the gene counts found in the pathway. The colors 
medRxiv preprint doi: https://doi.org/10.1101/2021.02.25.21252462; this version posted March 1, 2021. The copyright holder for this preprint (which was not certified by peer review) is the author/funder, who has granted medRxiv a license to display the preprint in perpetuity.

It is made available under a CC-BY-NC-ND 4.0 International license .

675 indicate the hypergeometric test p-values. The pathways indicate a stronger DNA-binding 676 transcription activity.

S1 Figure. The workflow of curating gene expression signature matrix in each tissue

679 Single cell data across multiple cell types in tissue is firstly imputed by SAVER-X and then 680 significant differentially expressed (DE) genes are identified based on cell-type level DE analysis.

681 Finally, for those identified DE genes, their average gene expression levels are computed within 682 each cell type.

683 S2 Figure. The cell type-trait associations across 55 traits identified by cWAS

684 In 36 tissues, the significant/most-significant associated cell types are shown in the figure. Blue 685 colors indicate the negative correlations between traits and the corresponding associated cell type 686 proportion while red colors indicate the positive correlations.

687 S3 Figure. Cell type expression pattern of breast cancer (BC)-associated gene identified by TWAS analysis

689 a) As in previous figures, the star indicates the significant cell types after Bonferroni correction in 690 whole blood. The fold indicates (x axis) the enrichment level of BC-associated genes in those 691 genes with high expression specificity in the corresponding cell type. b) This figure shows the 692 expression level of identified BC-associated genes in different cell types of whole blood.

693 S4 Figure. Survival analysis results of breast cancer patients in TCGA

694 Here we consider the cell type proportion estimated based on the assayed expression level in tumor 695 tissues from TCGA. a) In patients of European ancestry with basal breast cancer, only patients 696 with the top $10 \%$ and bottom $10 \%$ proportion of $\mathrm{CD}^{+} \mathrm{T}$ cells were considered. b) In Luminal A 697 patients with European ancestry, only patients with top $8 \%$ and bottom $8 \%$ proportion of CD $8^{+} \mathrm{T}$ 
medRxiv preprint doi: https://doi.org/10.1101/2021.02.25.21252462; this version posted March 1, 2021. The copyright holder for this preprint (which was not certified by peer review) is the author/funder, who has granted medRxiv a license to display the preprint in perpetuity.

It is made available under a CC-BY-NC-ND 4.0 International license .

698 cells were considered. c) In luminal B patients of European ancestry, only patients with the top

$69920 \%$ and bottom $20 \%$ proportion of $\mathrm{CD}^{+} \mathrm{T}$ cells were considered.

\section{S5 Figure. MAGMA analysis results of IPF and COPD GWAS summary stats}

701 In all figures, the vertical dash line indicates the significance threshold after Bonferroni correction.

702 The red bars indicate the corresponding cell types of interest in IPF and COPD. a) Bar plots of

703 MAGMA cell type association results between IPF and all cell types of the MAGMA processed

704 GSE93374_Mouse_Arc_ME_level2 dataset $^{53}$. Fibroblast-related cell types are highlighted in red.

705 The grey dashed line represents the 0.05 significance level. b) Bar plots of MAGMA cell type

706 association results between COPD and cell types from lung tissue of the MAGMA processed

707 TabulaMuris_FACS_all dataset ${ }^{54}$. Endothelial-related cell types are highlighted in red. The grey

708 dashed line represents the 0.05 significance level. c) Bar plots of MAGMA cell type association

709 results between COPD and all cell types from the MAGMA processed

710 GSE99235_Mouse_Lung_Vascular dataset. Endothelial-related cell types are highlighted in red.

711 The grey dashed line represents the 0.05 significance level.

712 S6 Figure. IPF myofibroblast and COPD endothelial cell type proportion validation in the

713 separate scRNA-seq atlas.

714 a) Boxplots of cell-type proportions comparison across IPF, COPD, and controls in lung tissue.

715 The horizontal axis represents the major cell types. The vertical axis is the cell type proportions.

716 The immune cells are the majority of the data. The cell type proportion has a non-negligible

717 variance across different conditions. b) Boxplots of two endothelial subtype proportions

718 comparison between COPD and controls. The vertical axis represents cell-type proportions. To

719 compare the cell type proportion distributions between COPD and controls, we conducted a t-test

720 which was not significant. However, the direction is consistent with cWAS finding for vascular 
medRxiv preprint doi: https://doi.org/10.1101/2021.02.25.21252462; this version posted March 1, 2021. The copyright holder for this preprint (which was not certified by peer review) is the author/funder, who has granted medRxiv a license to display the preprint in perpetuity. It is made available under a CC-BY-NC-ND 4.0 International license.

721 endothelial. We still consider these results inconclusive due to the low endothelial cell counts. c)

722 Dot plots of GSEA on IPF myofibroblast down-regulated genes. The dot size is the gene counts

723 found in the pathway. The colors indicate the hypergeometric test p-values. d) Dot plots of GSEA

724 on COPD endothelial down-regulated genes. The dot size is the gene counts found in the pathway.

725 The colors indicate the hypergeometric test p-values.

726

727

728 S Table 1. Statistical power and type I error of FUMA in the simulation study

729 S Table 2. HCL tissues used in the analysis

730 S Table 3. GWAS summary statistics for 55 traits used in the trait-trait correlation analysis

731 S Table 4. Shared cell types (mainly immune cells) in all tissues

732 S Table 5. cWAS test results in all HCL tissues for 55 traits

733 S Table 6. scRNA-seq data sets used for MAGMA analysis

734

735

736

737

738

739

740

$741 \quad$ References

743 1. Finucane, H. K. et al. Heritability enrichment of specifically expressed genes identifies 
medRxiv preprint doi: https://doi.org/10.1101/2021.02.25.21252462; this version posted March 1, 2021. The copyright holder for this preprint (which was not certified by peer review) is the author/funder, who has granted medRxiv a license to display the preprint in perpetuity.

It is made available under a CC-BY-NC-ND 4.0 International license .

disease-relevant tissues and cell types. Nat. Genet. (2018) doi:10.1038/s41588-018-0081-

4.

746 2. de Leeuw, C. A., Mooij, J. M., Heskes, T. \& Posthuma, D. MAGMA: Generalized GeneSet Analysis of GWAS Data. PLoS Comput. Biol. (2015) doi:10.1371/journal.pcbi.1004219.

3. Watanabe, K., Umićević Mirkov, M., de Leeuw, C. A., van den Heuvel, M. P. \& Posthuma, D. Genetic mapping of cell type specificity for complex traits. Nat. Commun. (2019) doi:10.1038/s41467-019-11181-1.

4. Tansey, K. E. \& Hill, M. J. Enrichment of schizophrenia heritability in both neuronal and glia cell regulatory elements. Transl. Psychiatry (2018) doi:10.1038/s41398-017-0053-y.

754 5. Hannon, E., Marzi, S. J., Schalkwyk, L. S. \& Mill, J. Genetic risk variants for brain disorders are enriched in cortical H3K27ac domains. Mol. Brain (2019)

6. Behan, F. M. et al. Prioritization of cancer therapeutic targets using CRISPR-Cas9 screens. Nature (2019) doi:10.1038/s41586-019-1103-9.

759 7. Cano-Gamez, E. \& Trynka, G. From GWAS to Function: Using Functional Genomics to Identify the Mechanisms Underlying Complex Diseases. Frontiers in Genetics (2020) doi:10.3389/fgene.2020.00424.

762 8. Baron, M. et al. A Single-Cell Transcriptomic Map of the Human and Mouse Pancreas

763 Reveals Inter- and Intra-cell Population Structure. Cell Syst. (2016)

764 doi:10.1016/j.cels.2016.08.011.

7659 Smith, G. D. Mendelian randomization for strengthening causal inference in observational 766 studies: Application to gene $\times$ environment interactions. Perspect. Psychol. Sci. (2010) 
medRxiv preprint doi: https://doi.org/10.1101/2021.02.25.21252462; this version posted March 1, 2021. The copyright holder for this preprint (which was not certified by peer review) is the author/funder, who has granted medRxiv a license to display the preprint in perpetuity.

It is made available under a CC-BY-NC-ND 4.0 International license .

doi:10.1177/1745691610383505.

768 10. Sekula, P., Del Greco, F. M., Pattaro, C. \& Köttgen, A. Mendelian randomization as an Nephrology (2016) doi:10.1681/ASN.2016010098.

771 11. Reiner, A. P. et al. Genome-Wide association study of white blood cell count in 16,388 african americans: The continental Origins and Genetic Epidemiology network (COGENT). PLoS Genet. (2011) doi:10.1371/journal.pgen.1002108.

12. Newman, A. M. et al. Robust enumeration of cell subsets from tissue expression profiles. Nat. Methods (2015) doi:10.1038/nmeth.3337.

13. Gustafsson, J. et al. Sources of variation in cell-type RNA-Seq profiles. PLoS One (2020) doi:10.1371/journal.pone.0239495.

14. Davies, N. M., Holmes, M. V. \& Davey Smith, G. Reading Mendelian randomisation studies: A guide, glossary, and checklist for clinicians. $B M J(2018)$ doi:10.1136/bmj.k601.

780 15. Glastonbury, C. A., Couto Alves, A., El-Sayed Moustafa, J. S. \& Small, K. S. Cell-Type Heterogeneity in Adipose Tissue Is Associated with Complex Traits and Reveals DiseaseRelevant Cell-Specific eQTLs. Am. J. Hum. Genet. (2019)

16. Kong, Y., Rastogi, D., Seoighe, C., Greally, J. M. \& Suzuki, M. Insights from deconvolution of cell subtype proportions enhance the interpretation of functional genomic data. PLoS One (2019) doi:10.1371/journal.pone.0215987.

787 17. Chen, B., Khodadoust, M. S., Liu, C. L., Newman, A. M. \& Alizadeh, A. A. Profiling (2018). doi:10.1007/978-1-4939-7493-1_12. 
medRxiv preprint doi: https://doi.org/10.1101/2021.02.25.21252462; this version posted March 1, 2021. The copyright holder for this preprint (which was not certified by peer review) is the author/funder, who has granted medRxiv a license to display the preprint in perpetuity.

It is made available under a CC-BY-NC-ND 4.0 International license .

790 18. Gamazon, E. R. et al. A gene-based association method for mapping traits using reference 791 transcriptome data. Nat. Genet. (2015) doi:10.1038/ng.3367.

792 19. Gusev, A. et al. Integrative approaches for large-scale transcriptome-wide association studies. Nat. Genet. (2016) doi:10.1038/ng.3506.

794 20. Hu, Y. et al. A statistical framework for cross-tissue transcriptome-wide association analysis. Nat. Genet. 51, 568-576 (2019).

796 21. Bycroft, C. et al. The UK Biobank resource with deep phenotyping and genomic data. Nature (2018) doi:10.1038/s41586-018-0579-z.

22. Han, X. et al. Construction of a human cell landscape at single-cell level. Nature (2020) doi:10.1038/s41586-020-2157-4.

800 23. Lu, Q. et al. Systematic tissue-specific functional annotation of the human genome highlights immune-related DNA elements for late-onset Alzheimer's disease. PLoS Genet. (2017) doi:10.1371/journal.pgen.1006933.

803 24. Wang, W. et al. Age-Related Dopaminergic Innervation Augments T Helper 2-Type Allergic Inflammation in the Postnatal Lung. Immunity (2019) doi:10.1016/j.immuni.2019.10.002.

806 25. Tränkner, D., Hahne, N., Sugino, K., Hoon, M. A. \& Zuker, C. Population of sensory neurons essential for asthmatic hyperreactivity of inflamed airways. Proc. Natl. Acad. Sci.

809 26. Michailidou, K. et al. Association analysis identifies 65 new breast cancer risk loci. Nature (2017) doi:10.1038/nature24284.

811 27. Huang, K. lin et al. Pathogenic Germline Variants in 10,389 Adult Cancers. Cell (2018) doi:10.1016/j.cell.2018.03.039. 
medRxiv preprint doi: https://doi.org/10.1101/2021.02.25.21252462; this version posted March 1, 2021. The copyright holder for this preprint (which was not certified by peer review) is the author/funder, who has granted medRxiv a license to display the preprint in perpetuity.

It is made available under a CC-BY-NC-ND 4.0 International license .

813 28. Liu, W. et al. Leveraging functional annotation to identify genes associated with complex

814 diseases. bioRxiv 529297 (2020) doi:10.1101/529297.

815 29. Tang, D., Park, S., Zhao, H. \& Birol, I. NITUMID: Nonnegative matrix factorizationbased Immune-TUmor MIcroenvironment Deconvolution. Bioinformatics (2020) doi:10.1093/bioinformatics/btz748.

818 30. Adams, T. et al. Single-cell RNA-seq reveals ectopic and aberrant lung-resident cell populations in idiopathic pulmonary fibrosis. Sci. Adv. (2020) doi:10.1126/sciadv.aba1983.

821 31. Allen, R. J. et al. Genome-wide association study of susceptibility to idiopathic pulmonary fibrosis. Am. J. Respir. Crit. Care Med. (2020) doi:10.1164/rccm.201905-1017OC.

823 32. Cho, M. H. et al. Risk loci for chronic obstructive pulmonary disease: A genome-wide association study and meta-analysis. Lancet Respir. Med. (2014) doi:10.1016/S22132600(14)70002-5.

33. Schruf, E. et al. Human lung fibroblast-to-myofibroblast transformation is not driven by an LDH5-dependent metabolic shift towards aerobic glycolysis. Respir. Res. (2019) doi:10.1186/s12931-019-1058-2.

829 34. Wynn, T. A. Integrating mechanisms of pulmonary fibrosis. J. Exp. Med. (2011) doi:10.1084/jem.20110551.

831 35. Moore, M. W. \& Herzog, E. L. Regulation and Relevance of Myofibroblast Responses in 832 Idiopathic Pulmonary Fibrosis. Current Pathobiology Reports (2013) doi:10.1007/s40139013-0017-8.

834 36. Sivakumar, P. et al. RNA sequencing of transplant-stage idiopathic pulmonary fibrosis lung reveals unique pathway regulation. ERJ Open Res. (2019) 
medRxiv preprint doi: https://doi.org/10.1101/2021.02.25.21252462; this version posted March 1, 2021. The copyright holder for this preprint (which was not certified by peer review) is the author/funder, who has granted medRxiv a license to display the preprint in perpetuity.

It is made available under a CC-BY-NC-ND 4.0 International license .

doi:10.1183/23120541.00117-2019.

837 37. Liu, W. et al. Leveraging functional annotation to identify genes associated with complex diseases. PLoS Comput. Biol. (2020) doi:10.1371/journal.pcbi.1008315.

38. Sakornsakolpat, P. et al. Genetic landscape of chronic obstructive pulmonary disease identifies heterogeneous cell-type and phenotype associations. Nat. Genet. (2019)

39. Frantz, C., Stewart, K. M. \& Weaver, V. M. The extracellular matrix at a glance. Journal of Cell Science (2010) doi:10.1242/jcs.023820.

40. Finucane, H. K. et al. Partitioning heritability by functional annotation using genomewide association summary statistics. Nat. Genet. 47, 1228 (2015).

846 41. Zhang, S. C. et al. Clinical implications of tumor-infiltrating immune cells in breast cancer. J. Cancer (2019) doi:10.7150/jca.35901.

848 42. Bense, R. D. et al. Relevance of tumor-infiltrating immune cell composition and functionality for disease outcome in breast cancer. Journal of the National Cancer Institute (2017) doi:10.1093/jnci/djw192.

851 43. Egelston, C. A. et al. Human breast tumor-infiltrating CD8+ T cells retain polyfunctionality despite PD-1 expression. Nat. Commun. (2018) doi:10.1038/s41467-

854 44. Mahmoud, S. M. A. et al. Tumor-infiltrating CD8+ lymphocytes predict clinical outcome in breast cancer. J. Clin. Oncol. (2011) doi:10.1200/JCO.2010.30.5037.

856 45. Rojas-Quintero, J., Wang, X. \& Owen, C. A. Endothelial cell death in emphysema: More 
medRxiv preprint doi: https://doi.org/10.1101/2021.02.25.21252462; this version posted March 1, 2021. The copyright holder for this preprint (which was not certified by peer review) is the author/funder, who has granted medRxiv a license to display the preprint in perpetuity.

It is made available under a CC-BY-NC-ND 4.0 International license .

859 46. Stockley, R. A. Neutrophils and the pathogenesis of COPD. in Chest (2002).

860 doi:10.1378/chest.121.5_suppl.151S.

861 47. Chambers, E., Rounds, S. \& Lu, Q. Pulmonary endothelial cell apoptosis in emphysema 862 and acute lung injury. in Advances in Anatomy Embryology and Cell Biology (2018).

863 doi:10.1007/978-3-319-68483-3_4.

864

48. Cho, M. H. et al. A genome-wide association study of emphysema and airway quantitative imaging phenotypes. Am. J. Respir. Crit. Care Med. (2015) doi:10.1164/rccm.201501-

866 01480C.

49. Cuomo, A. S. E. et al. Single-cell RNA-sequencing of differentiating iPS cells reveals dynamic genetic effects on gene expression. Nat. Commun. (2020) doi:10.1038/s41467020-14457-Z.

50. Wang, J. et al. Transfer learning in single-cell transcriptomics improves data denoising

872 51. Finak, G. et al. MAST: A flexible statistical framework for assessing transcriptional changes and characterizing heterogeneity in single-cell RNA sequencing data. Genome Biol. (2015) doi:10.1186/s13059-015-0844-5.

52. Kim, W. J. et al. Comprehensive analysis of transcriptome sequencing data in the lung

877 53. Campbell, J. N. et al. A molecular census of arcuate hypothalamus and median eminence 878 cell types. Nat. Neurosci. (2017) doi:10.1038/nn.4495.

879 54. Vanlandewijck, M. et al. A molecular atlas of cell types and zonation in the brain vasculature. Nature (2018) doi:10.1038/nature25739. 
COPD GWAS summary statistics

\begin{tabular}{|c|c|c|}
\hline SNP & Effect allele & P value \\
\hline rs1 & $\mathrm{C}$ & $1 \mathrm{e}-5$ \\
\hline $\mathrm{rs} 2$ & $\mathrm{~T}$ & 0.06 \\
\hline$\ldots$ & $\ldots$ & $\ldots$ \\
\hline
\end{tabular}

\section{Imputation}

Imputed "bulk" gene expression in lung

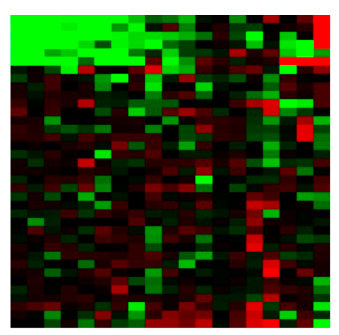

\section{Decomposition}

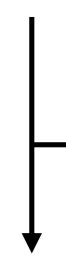

Estimated genetically regulated cell type proportions

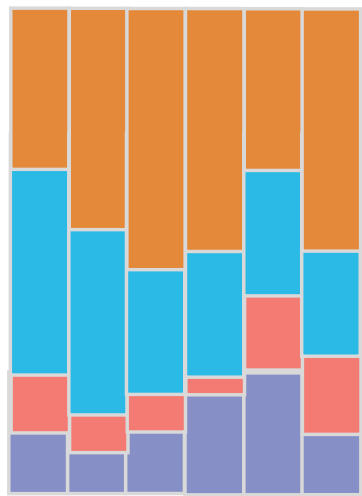

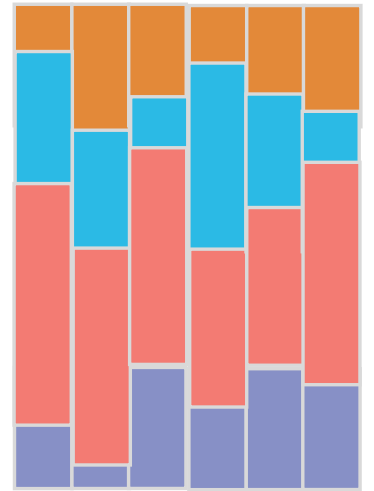

COPD
eQTL in lung from GTEx

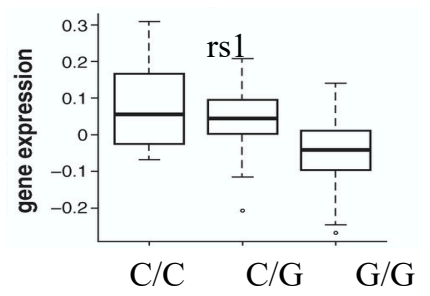

cell-type level expression in Lung
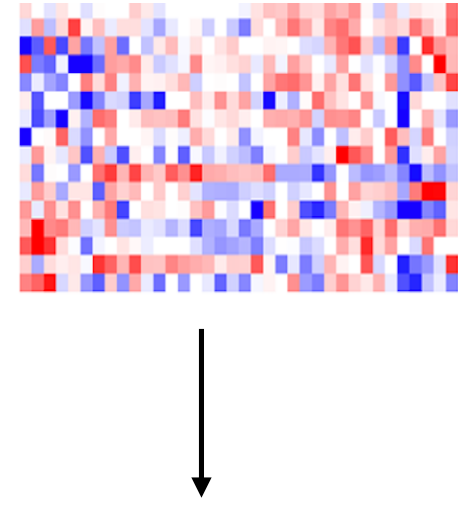

Cell-type specific signature profile in Lung

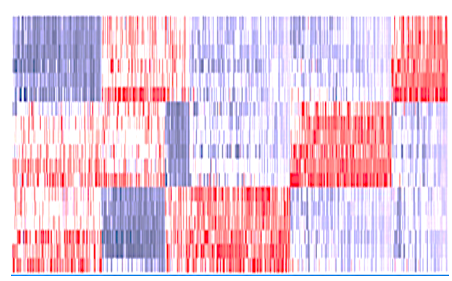

\section{Normal \\ Association test}

\begin{tabular}{|c|c|c|}
\hline Cell type & Z score & P value \\
\hline Endothelial & 5.6 & $2.14 \mathrm{e}-08$ \\
\hline Mast & 0.6 & 0.55 \\
\hline T cell & -1.7 & 0.08 \\
\hline Macrophage & 0.2 & 0.84 \\
\hline
\end{tabular}


a

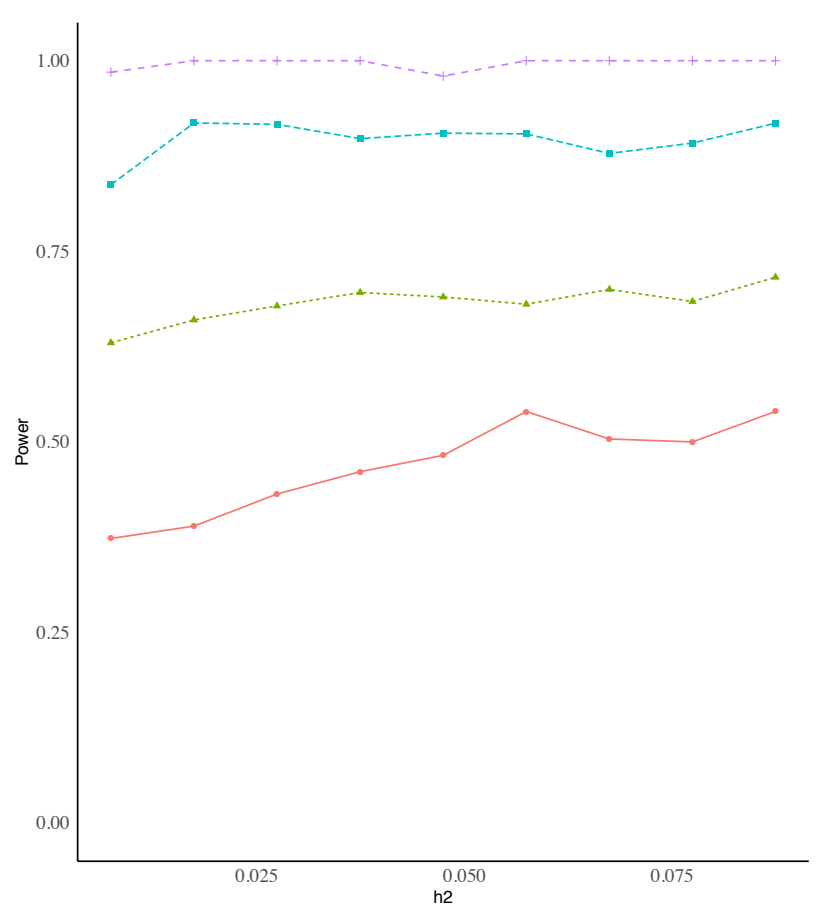

c

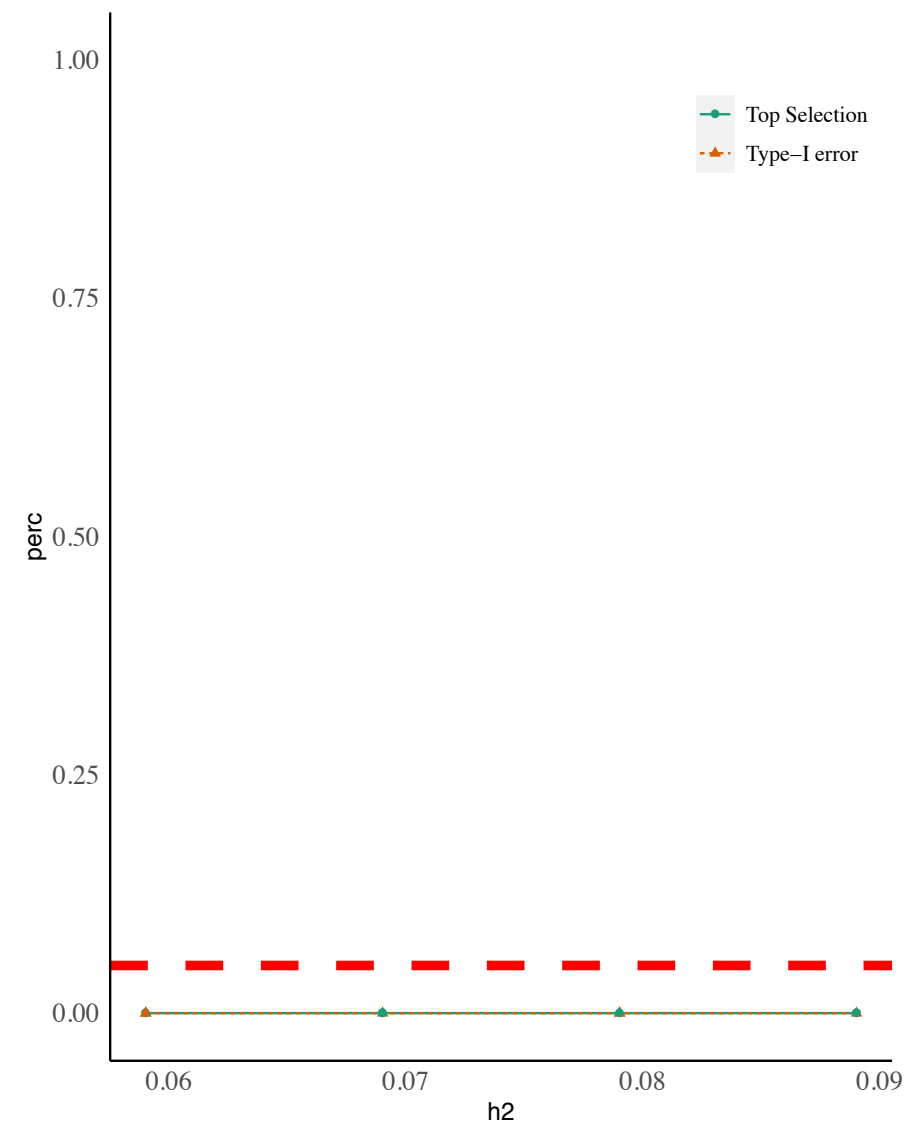

b

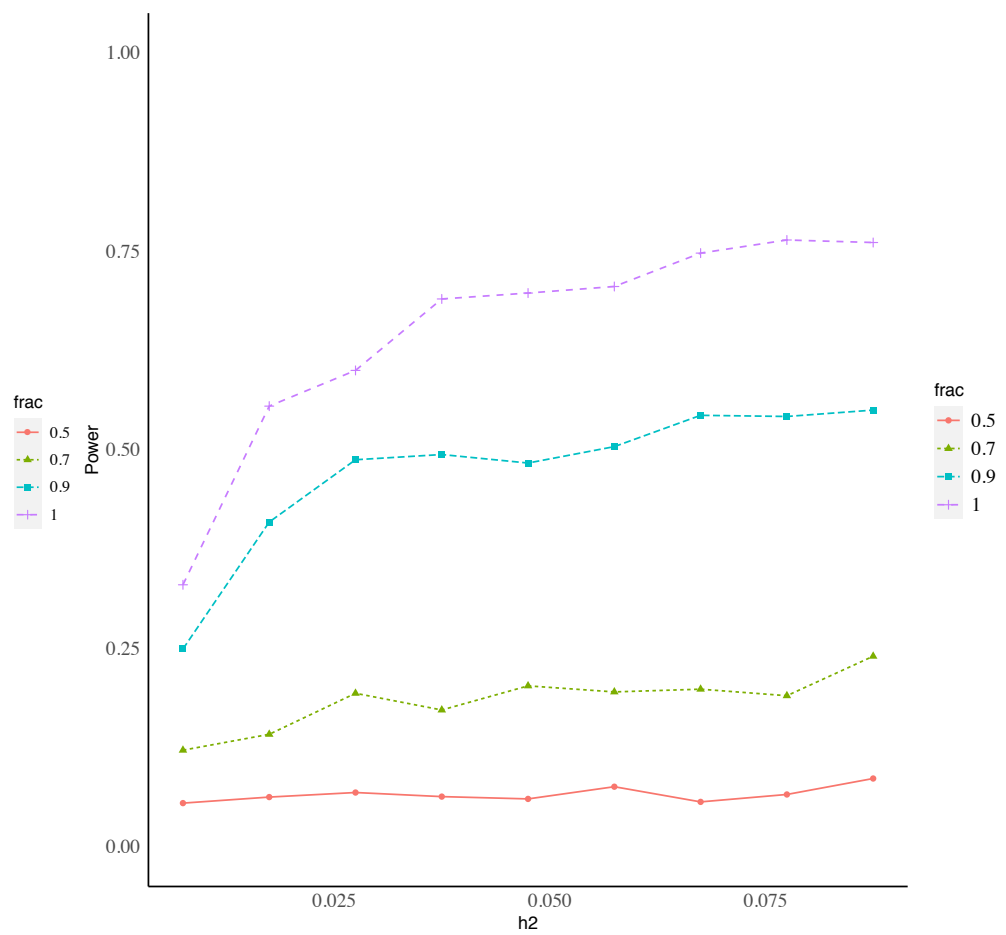

d

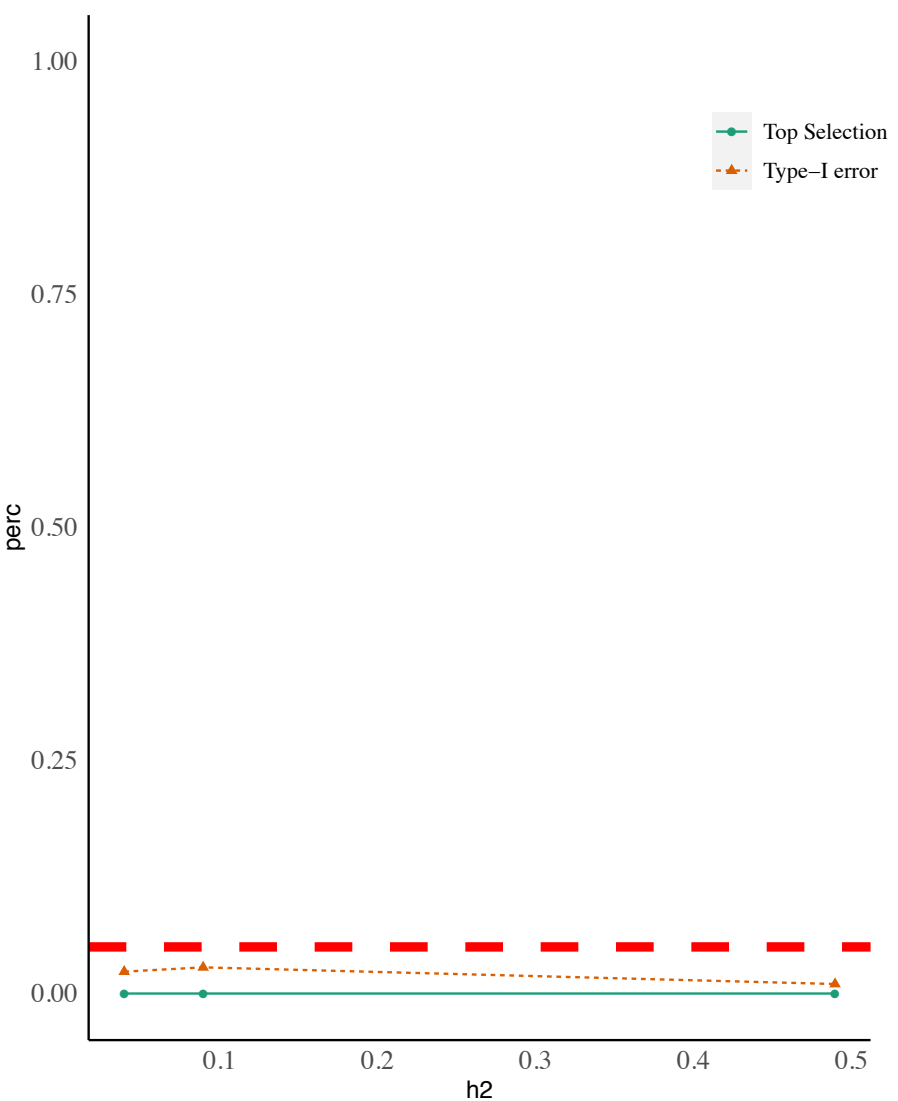

Figure 2 


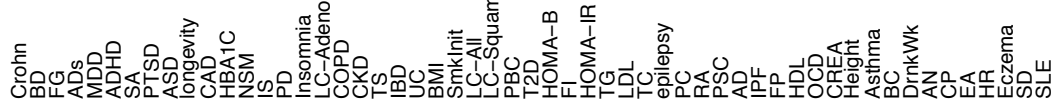

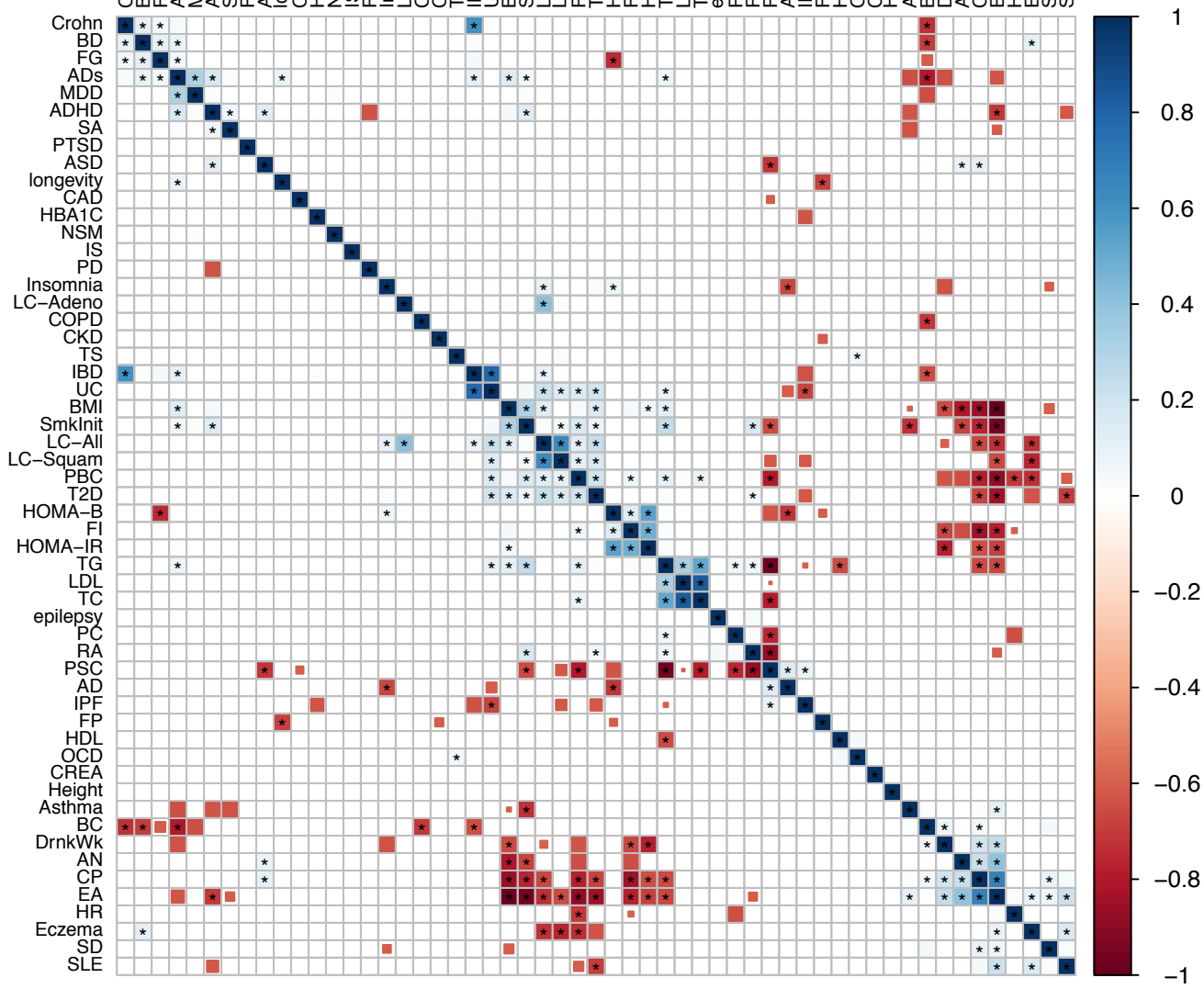

b

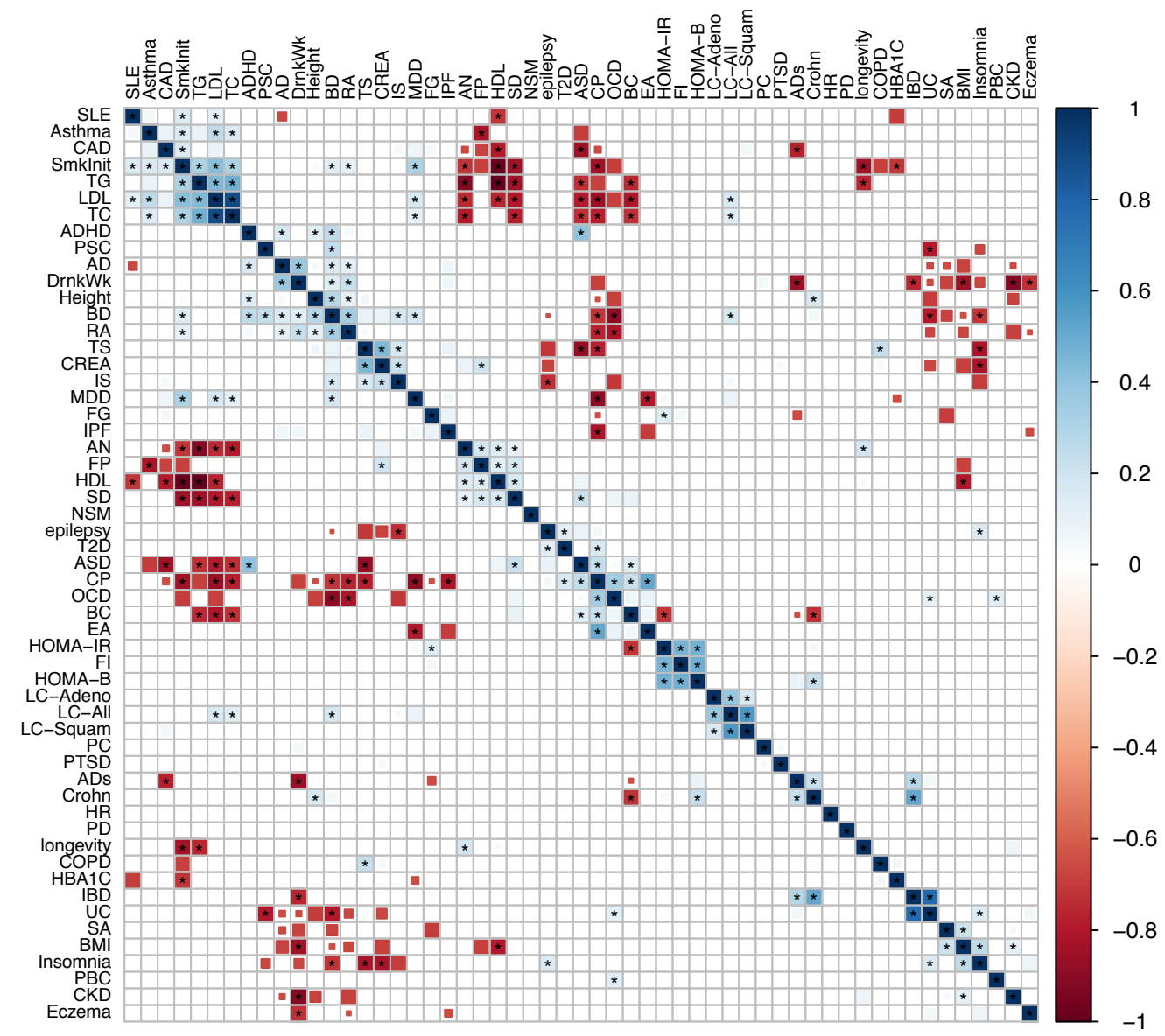


T.cells.regulatory..Tregs

T.cells.gamma.delta T.cells.follicular.helper

T.cells.CD8

T.cells.CD4.naive

T.cells.CD4.memory .resting T.cells.CD4.memory.activated

Plasma.cells

NK.cells.resting

$\overline{\overline{0}}$

NK.cells.activated

Neutrophils

Monocytes

Mast.cells.resting

Mast.cells.activated

Macrophages.M2

Macrophages.M1

Macrophages.M0

Eosinophils

Dendritic.cells.resting

Dendritic.cells.activated

B.cells.naive

B.cells.memory

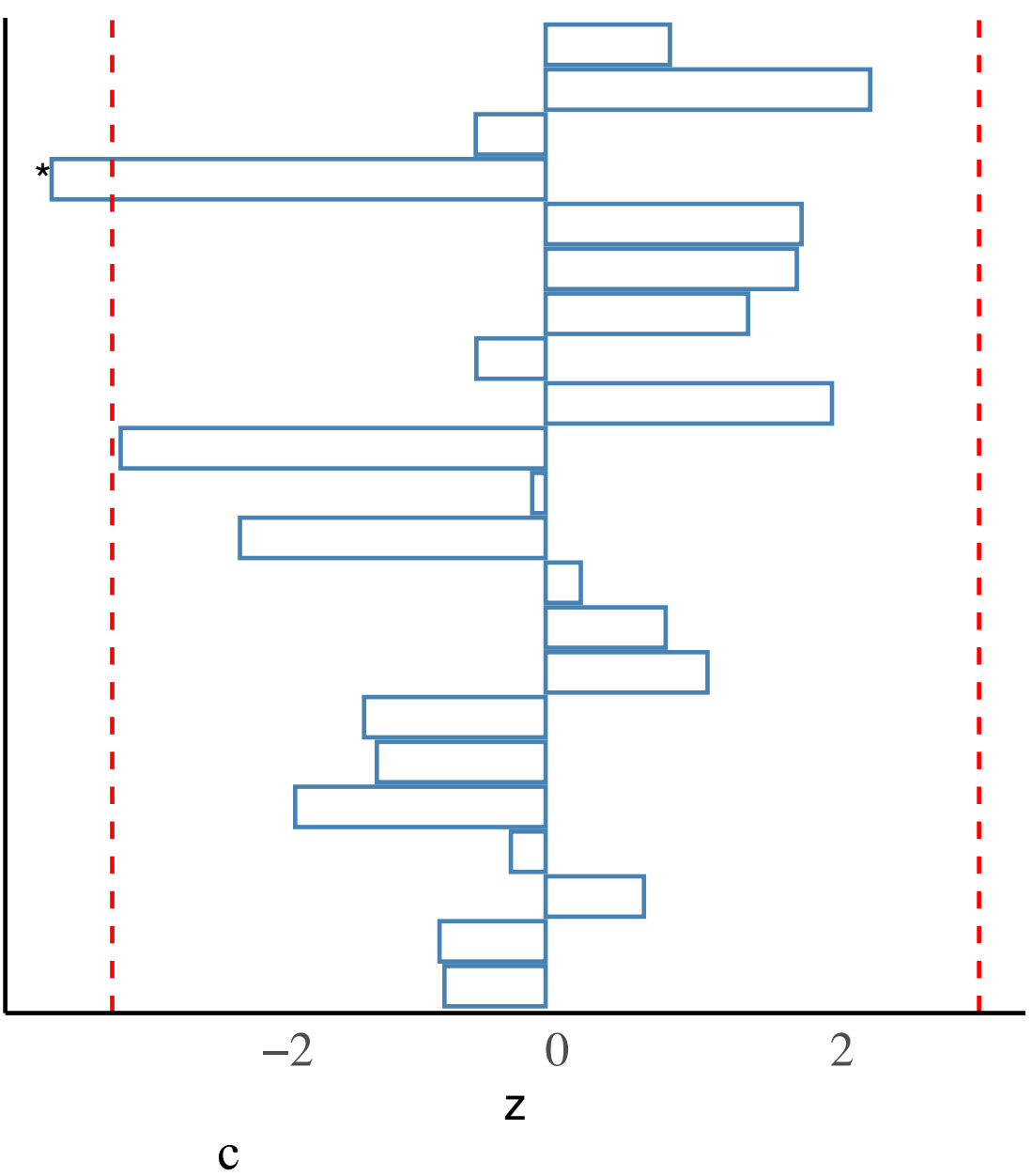

Cell Type Fraction of CD8 T cells $-<$ mean in $10 \%$ Xtrm Samp $->$ mean in $10 \%$ Xtrm Samp

Cell Type Fraction of CD8 T cells $-<$ mean in $40 \%$ Xtrm Samp $->$ mean in $40 \%$ Xtrm Samp

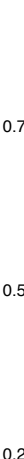

0.75
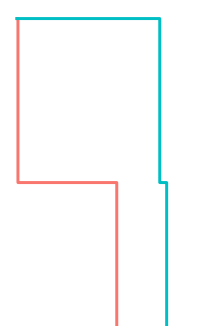

$\mathrm{p}=0.085$

0

25

50
Time(month)

75

100

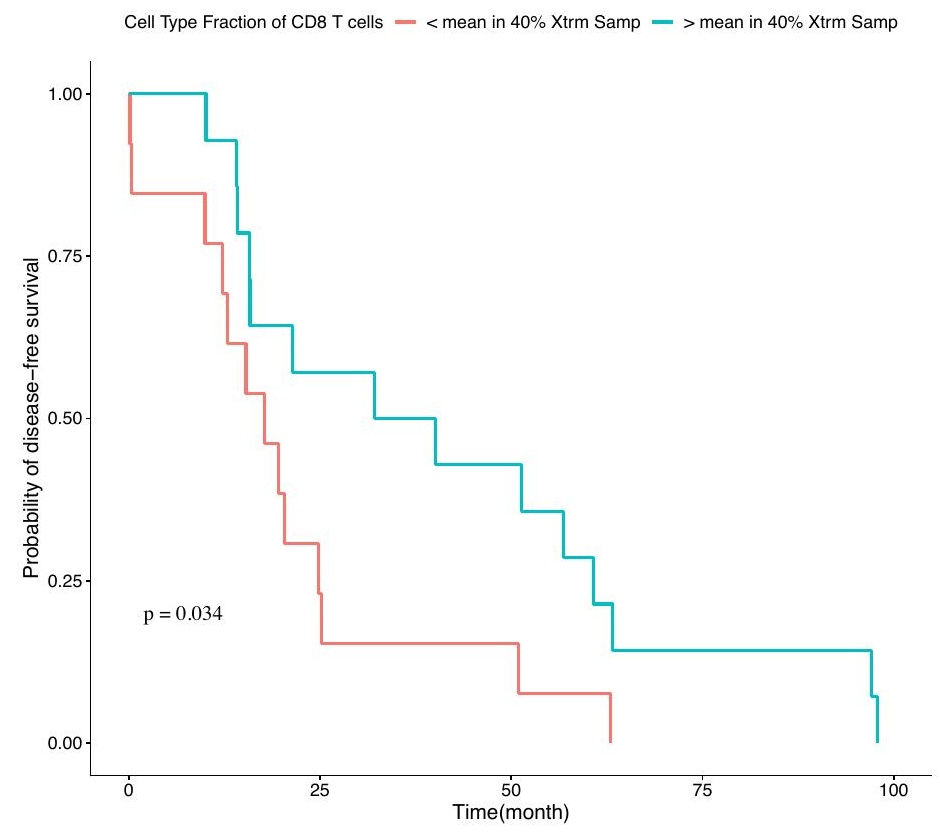

Figure 5 


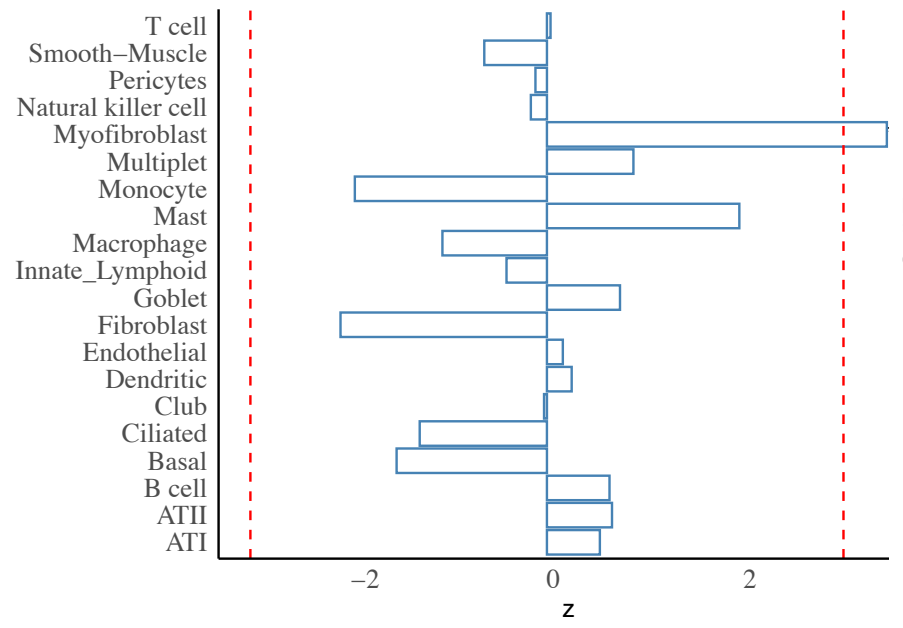

c

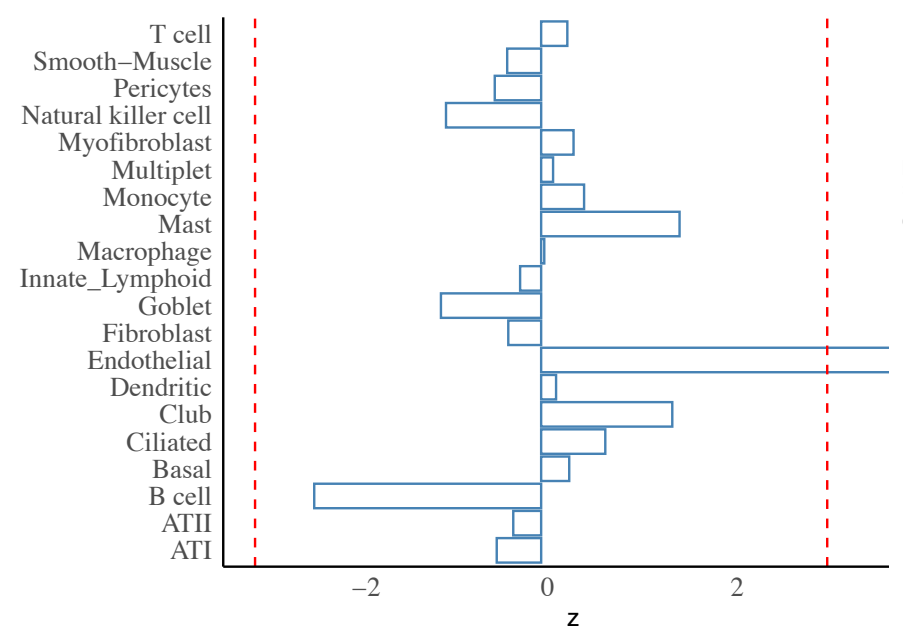

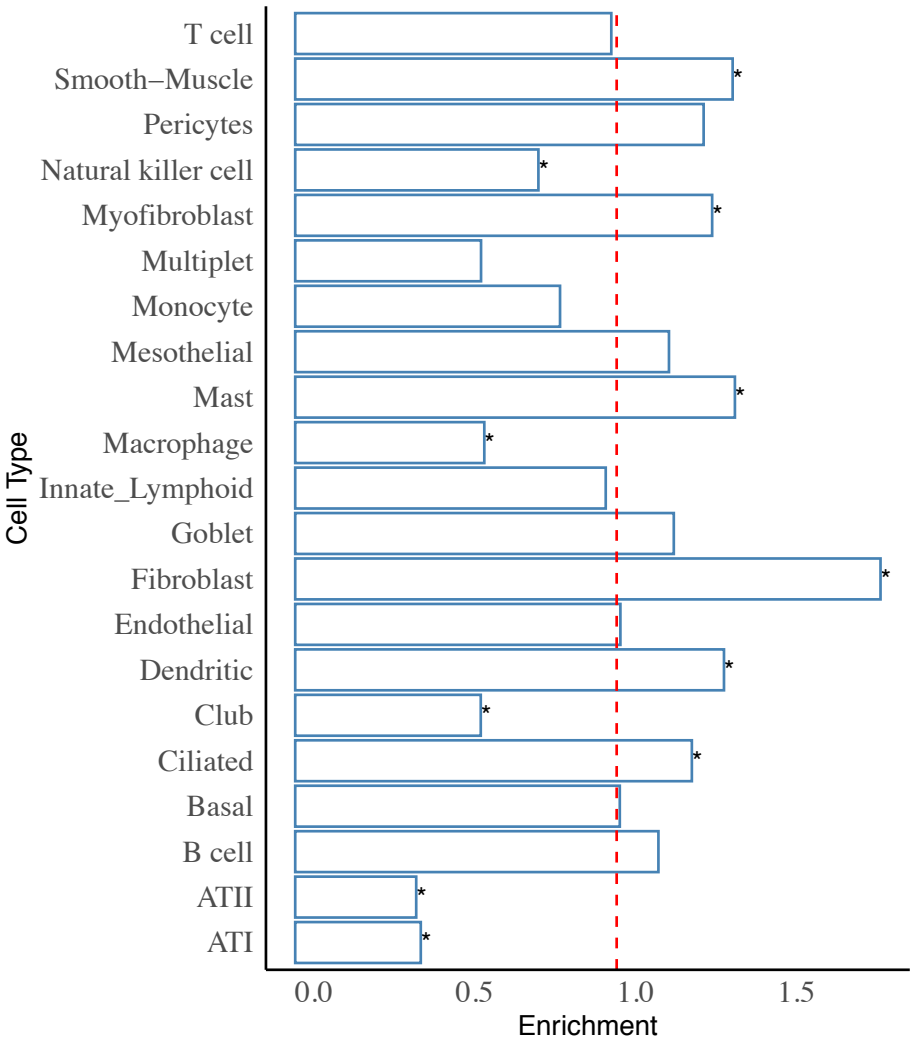

d

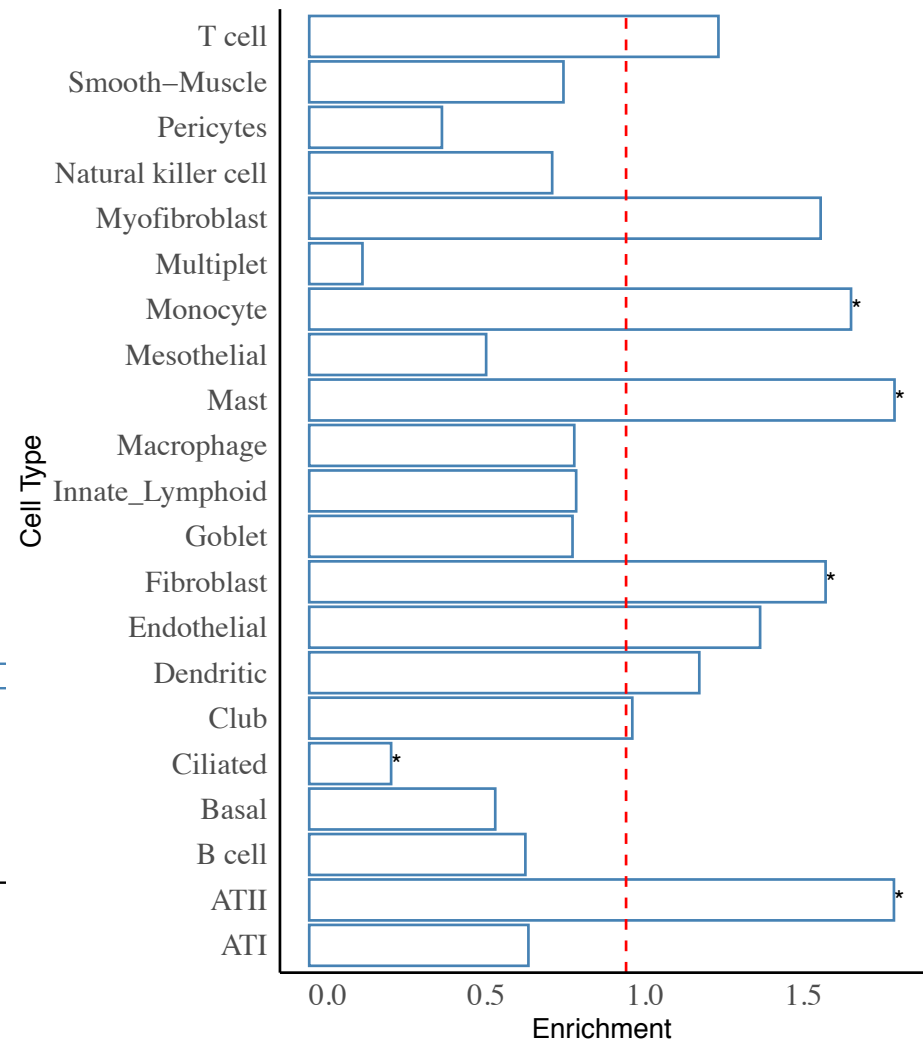

Figure 6 


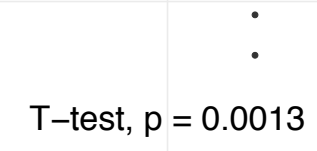

$0.075-$

Condition
官 Control

审 IPF

은
응.050-
음

C

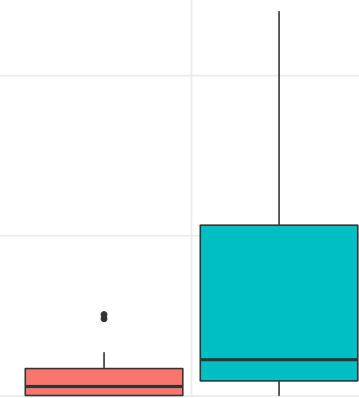

Myofibroblast

d
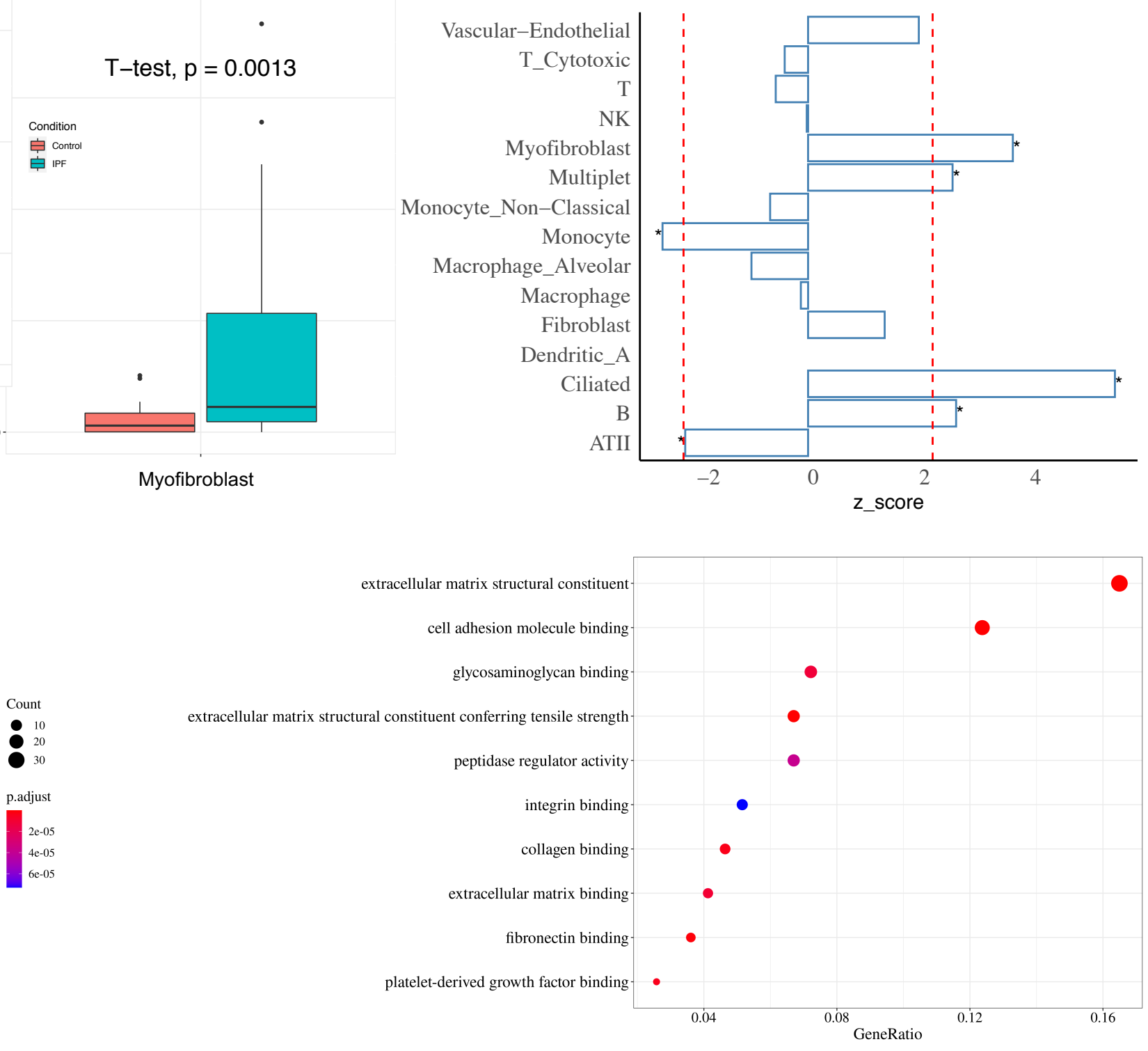

Count

3
6
9
12
15
p.adjust
0.01
0.02
0.03
T_Cytotoxic

$\mathrm{T}$

ofibroblast

Multiplet

Monocyte

crophage

dritic_A

ATII

z_score 


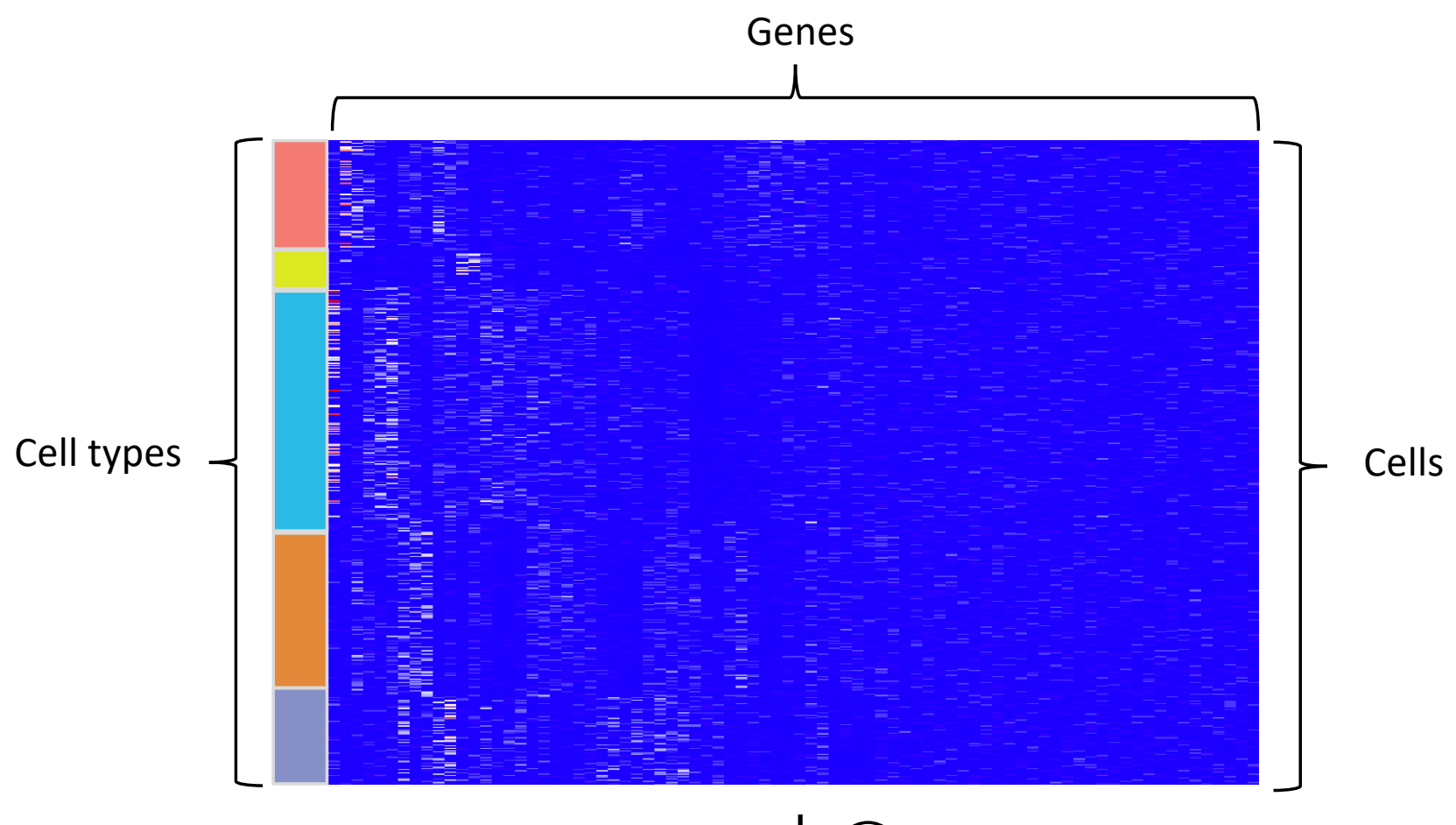

(1) Imputation by SAVER-X

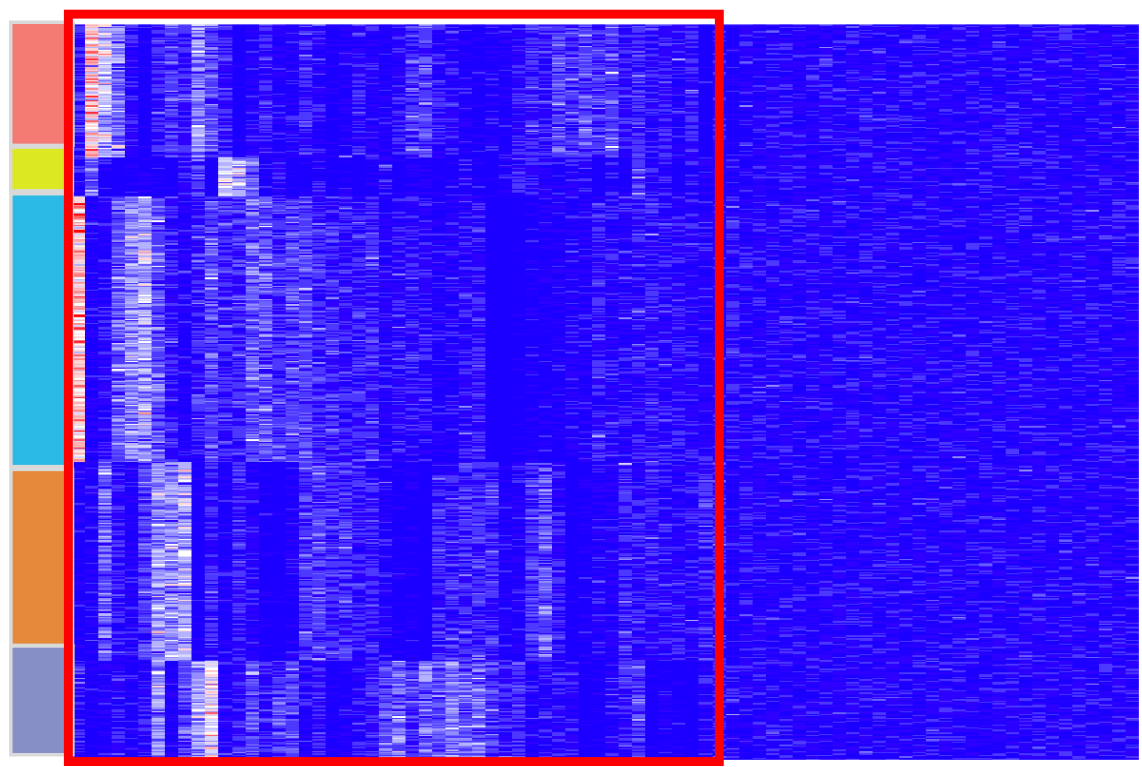

(2) Expression Matrix Curation with only GTEx DEGs (3) Average expression within cell types

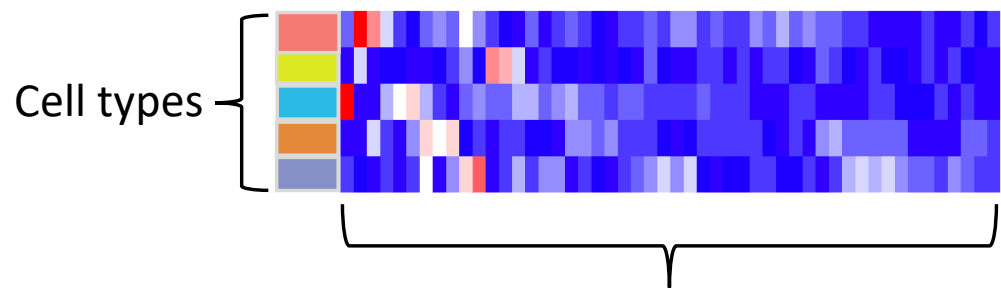

Signature Matrix

Genes 

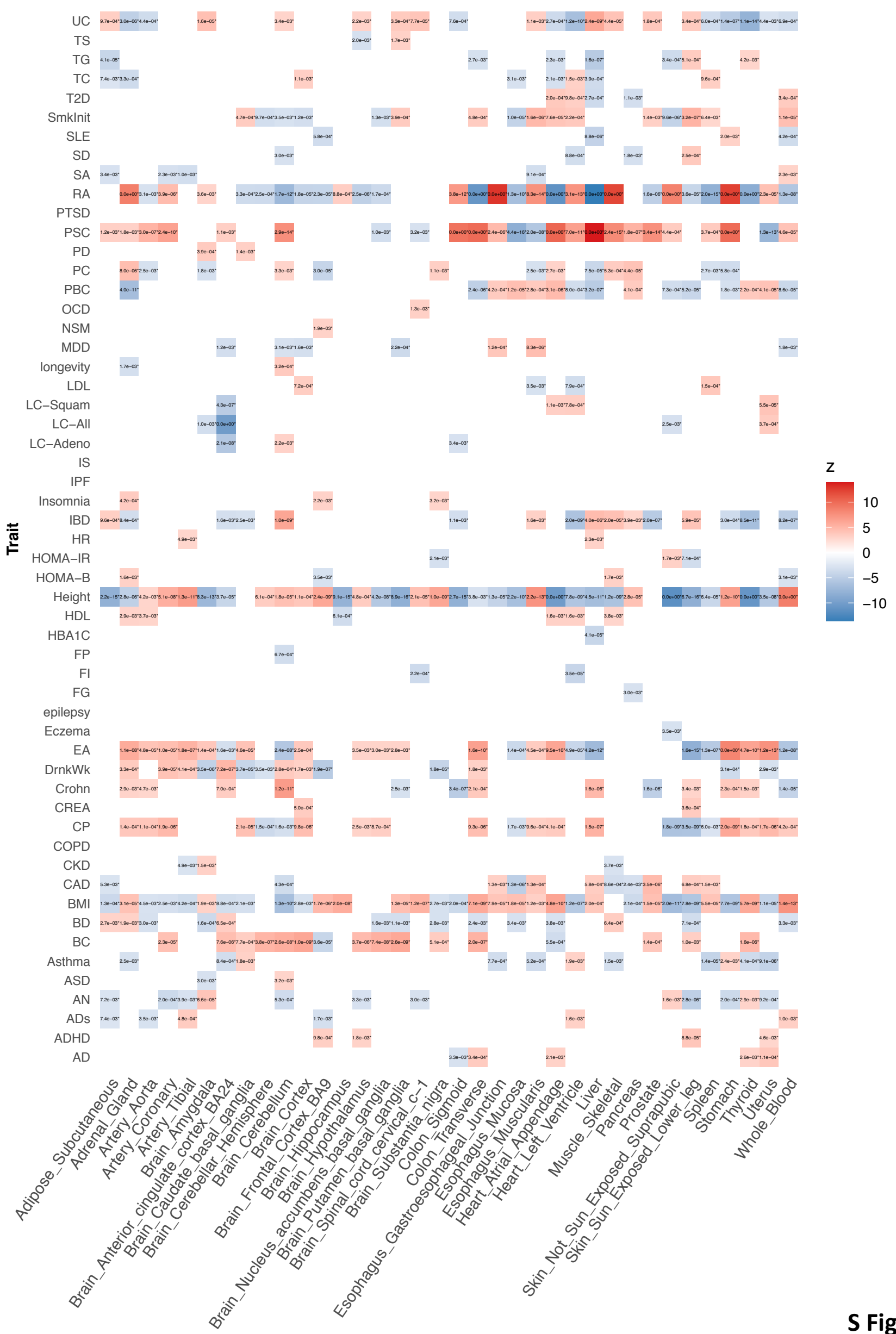

Tissue 


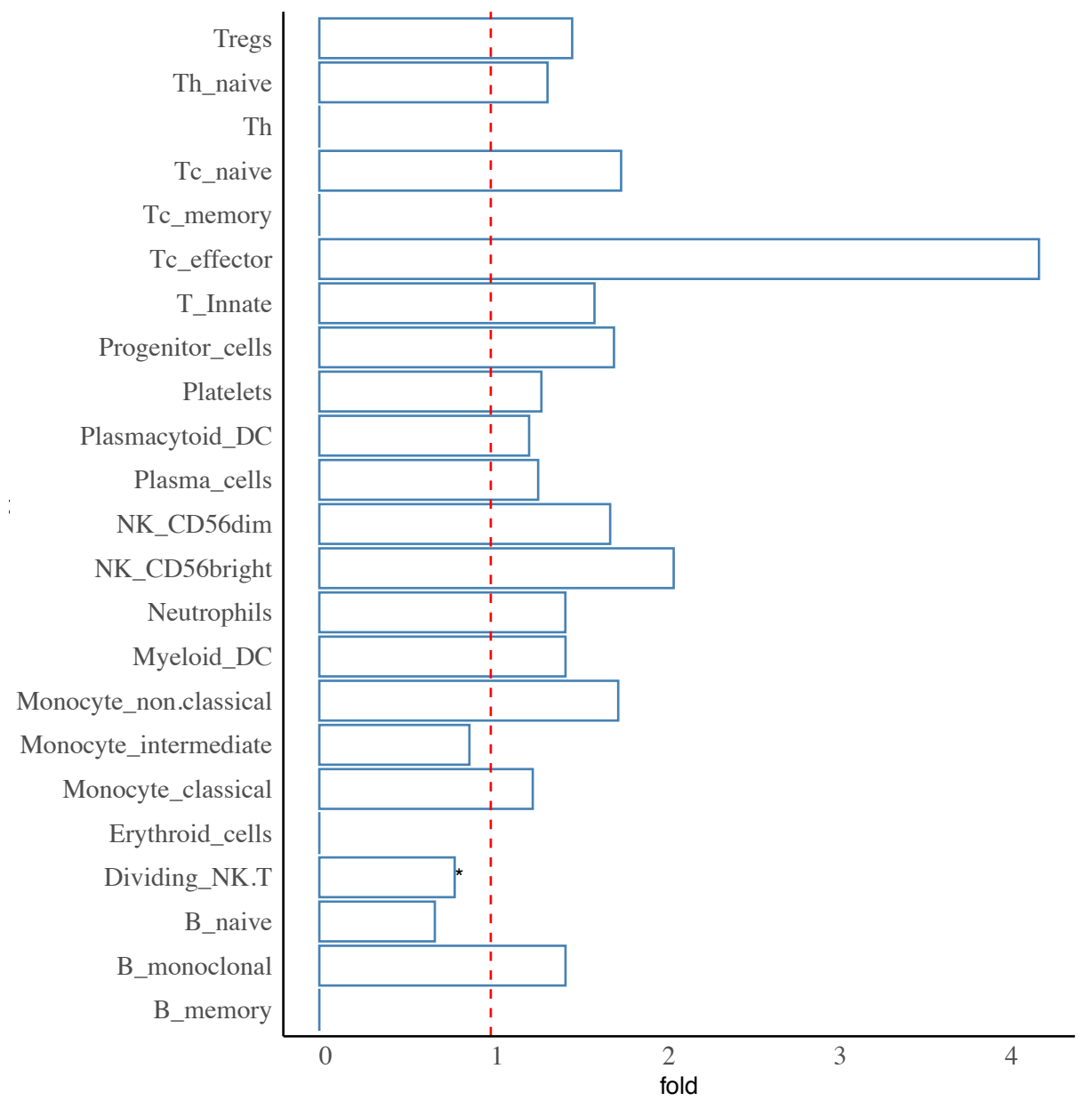

b

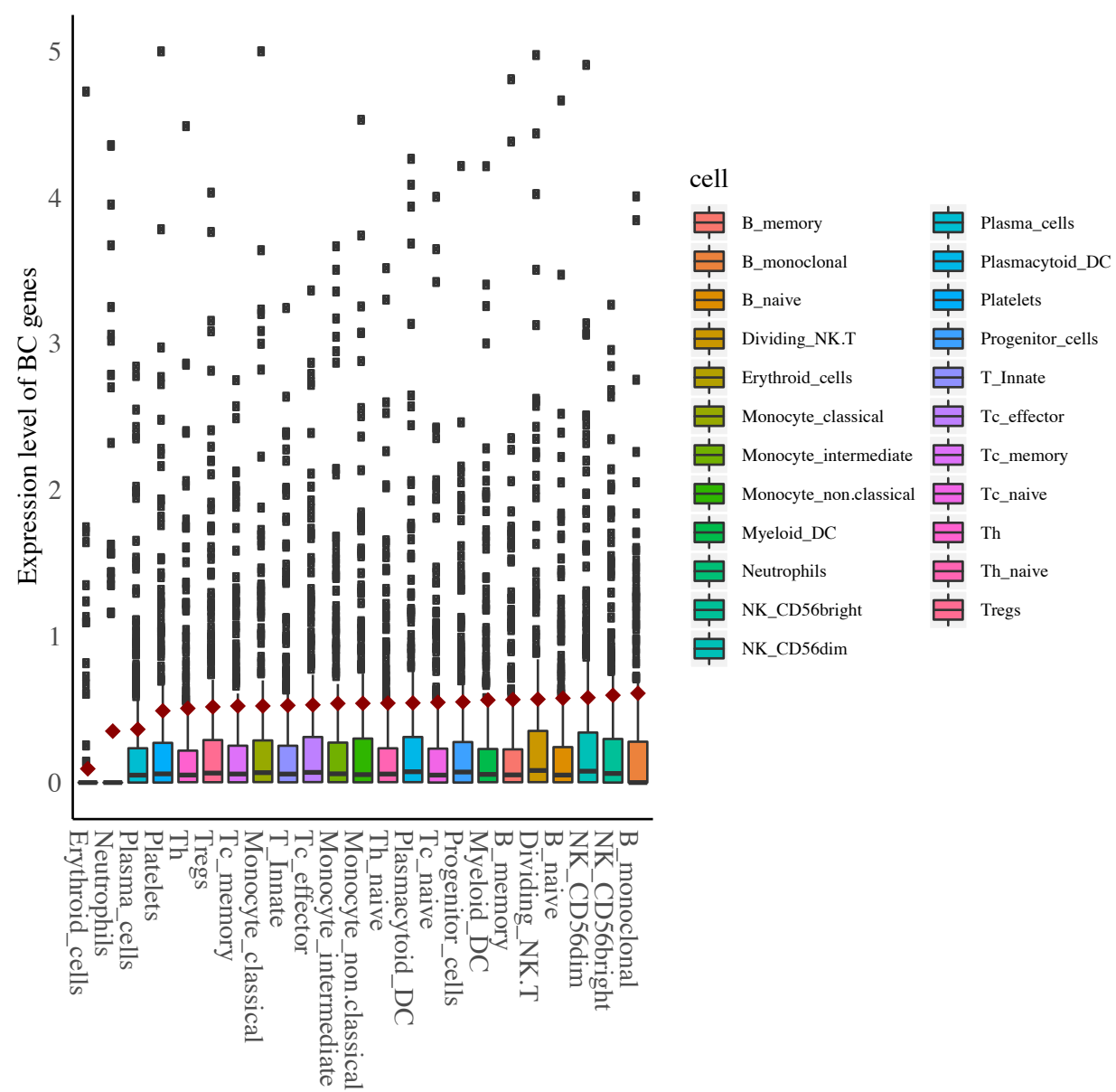


a

b

Cell Type Fraction of CD8 $+<$ mean in $10 \%$ Xtrm Samp $+>$ mean in $10 \%$ Xtrm Samp

Cell Type Fraction of CD8 $+<$ mean in $8 \%$ Xtrm Samp $+>$ mean in $8 \%$ Xtrm Samp
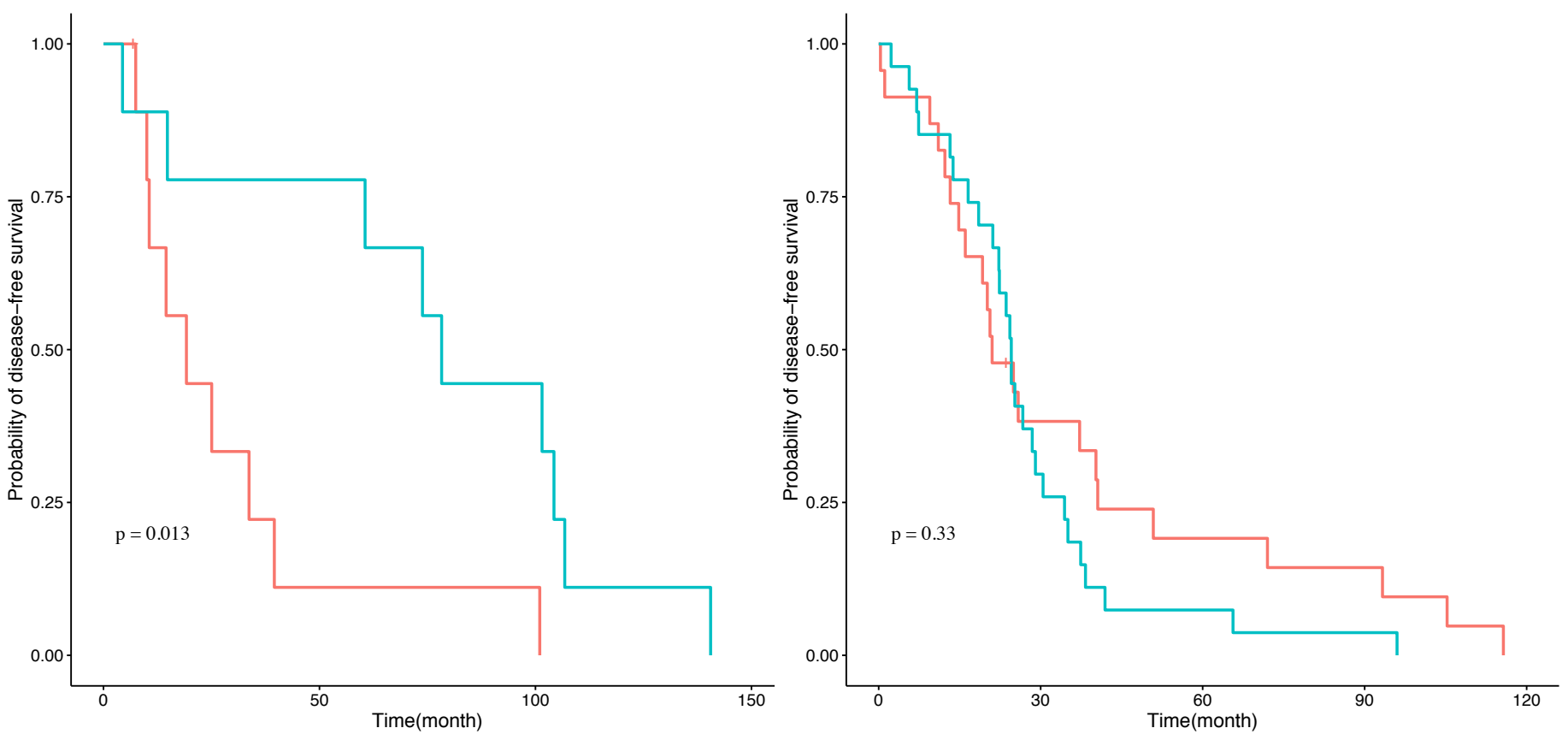

c

Cell Type Fraction of CD8 $+<$ mean in $20 \%$ Xtrm Samp $+>$ mean in $20 \%$ Xtrm Samp

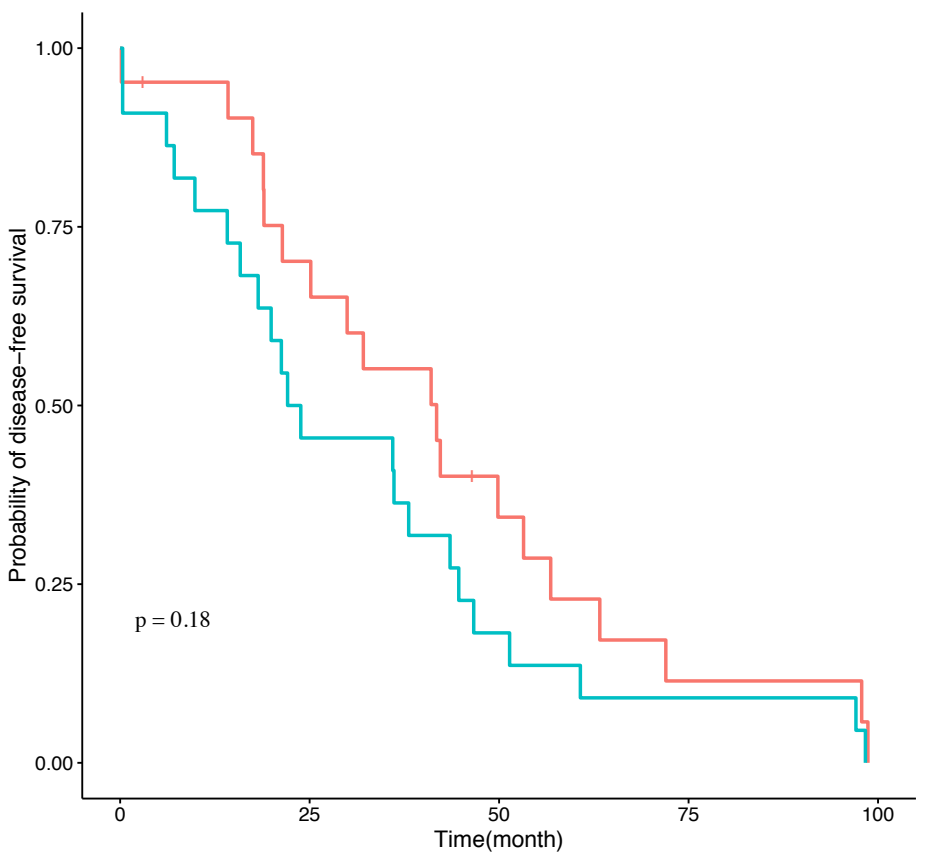

S Fig 4 
Pars_Tuber1B Fibroblasts1 -

Microglia -

Pars_Tuber1C -

b2 tanycytes2 -

Parstuber2B -

b2_tanycytes1 -

NG2 OPC1 -

Neurons2 -

Neurons 4 -

a1_tanycytes2 -

Pars_Tuber1A -

Neurons6 -

Parstuber2A -

Neurons1 -

Neurons3 -

PVMs -

b1 tanycytes -

a2_tanycytes -

Astrocytes -

Neurons5 -

Fibroblasts3 -

Fibroblasts2 -

Oligodendro4 -

Oligodendro5 -

Mural Cells2 -

a1_tanycytes 1 -

Oligodendro6 -

Endothelial -

Oligodendro2 -

Mural Cells1 -

NG2_OPC2 -

Ependymocy1 -

Oligodendro1 -

Oligodendro3 -

Ependymocy2 -

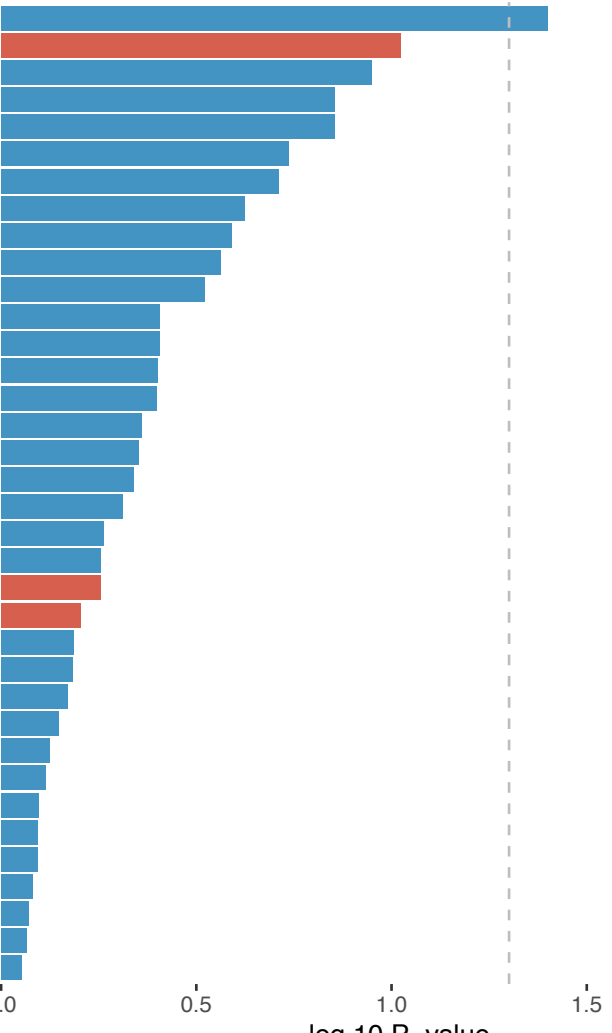

- $\log 10 \mathrm{P}-$ value

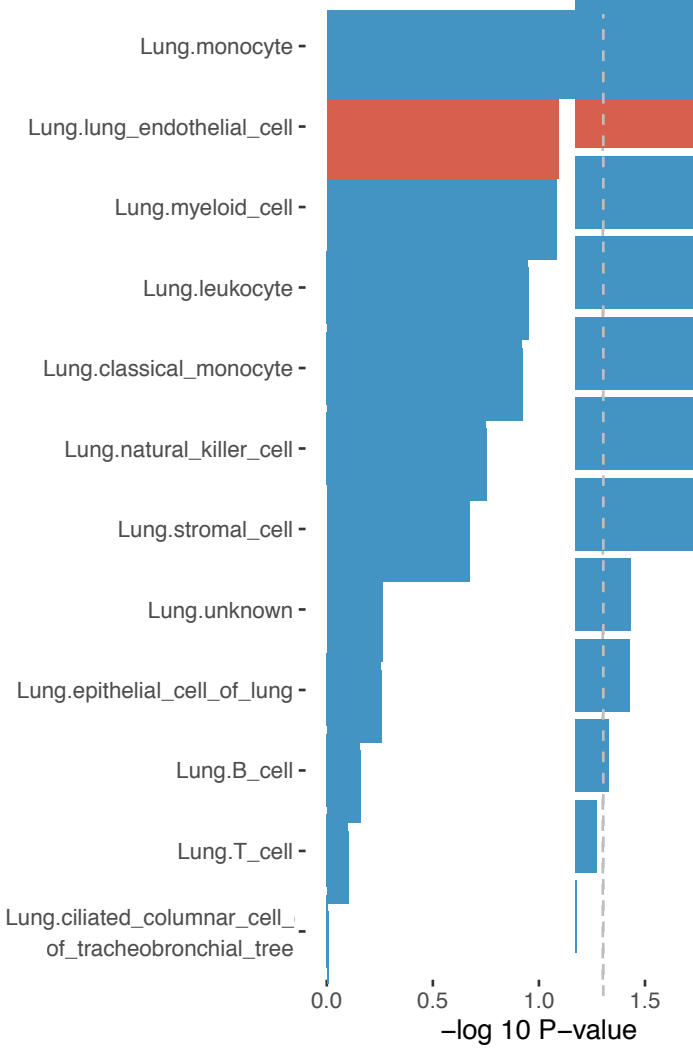

C

endothelial2 -

endothelial1 -

capillary_endothelial -

capillary_endothelial2 -

lymphatic_endothelial -

capillary_endothelial1 -

capillary_endothelial3 -

pericytes -

arterial_endothelial -

chondrocytes/perichondrium2 -

fibroblasts4 -

fibroblasts3 -

fibroblasts2 -
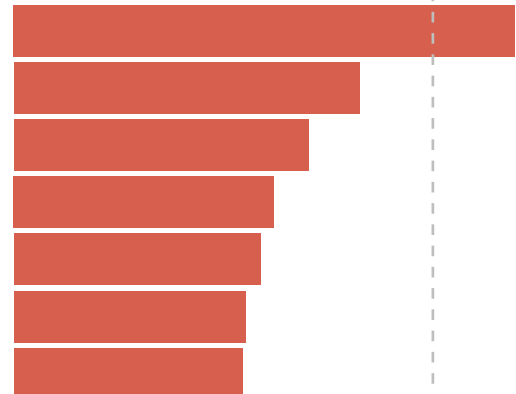

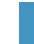

政 


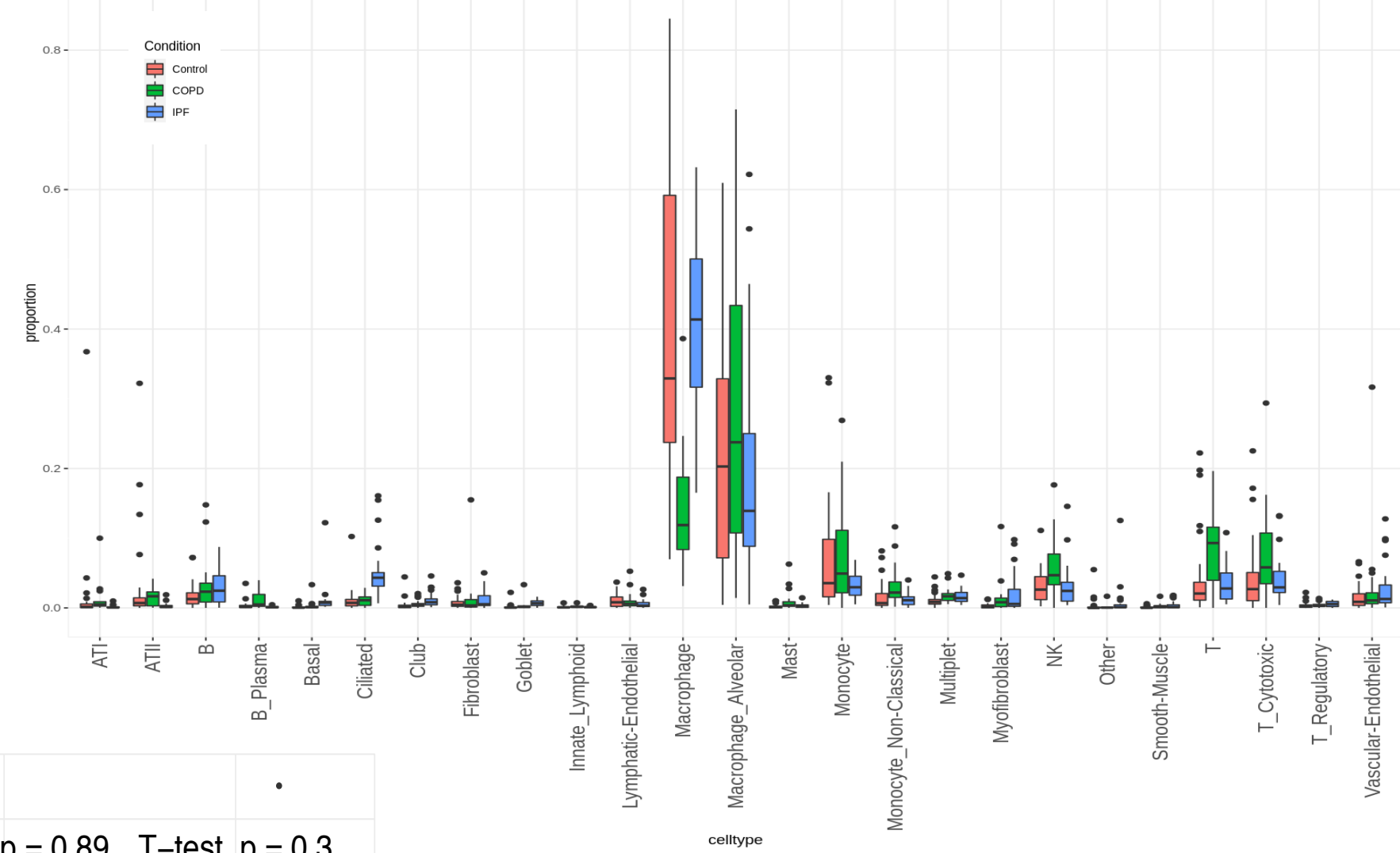

b
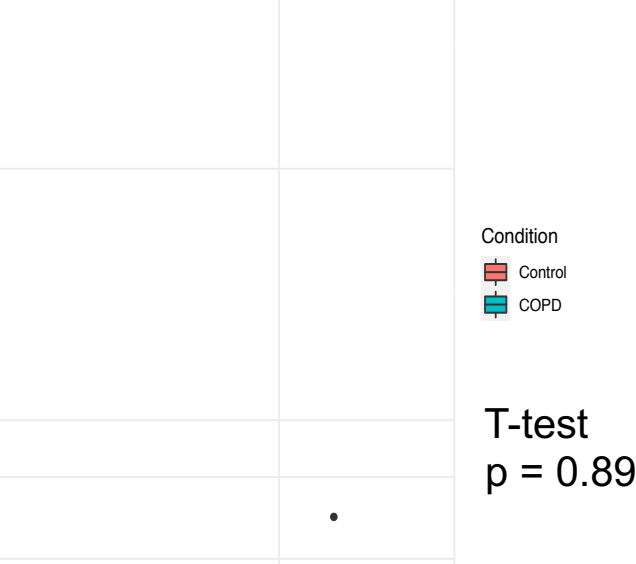

Lymphatic-Endothelial

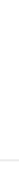

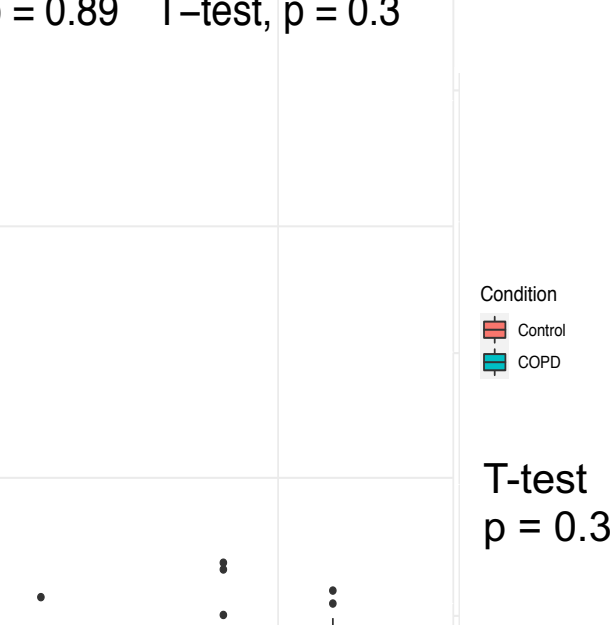

$0.0-$
C

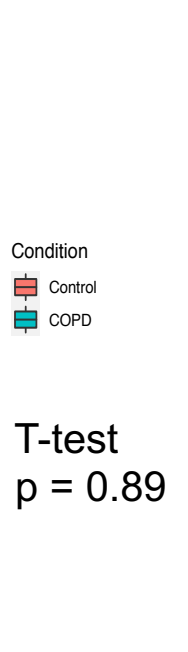

d extracellular matrix structural constituent- $\begin{array}{r}0.015 \\ 0.020\end{array}$

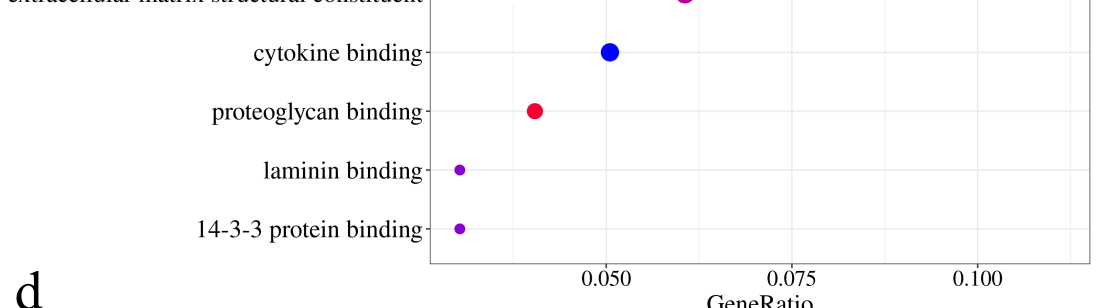

cell adhesion molecule binding Count

cadherin binding

peptide binding

carboxylic acid binding

organic acid binding

amyloid-beta binding

antioxidant activity

fatty acid binding

RAGE receptor binding

Toll-like receptor binding

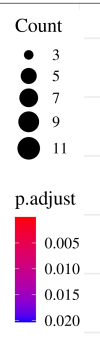

GeneRatio

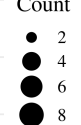

p.adjust

0.008

$-0.010$

0.012

0.014
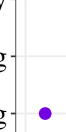